\title{
Systematic Review of Literature on Dry Port - Concept Evolution
}

\author{
Nabil Lamii, Fatimazahra Bentaleb, Mouhsene Fri, Kaoutar \\ Douaioui, Charif Mabrouki, El Alami Semma
}

Dry port plays an important role in supply chain management and mitigates seaport problems. The aim of this paper is to review the dry port concept over the different phases. Today there are different types of dry ports, different interpretations on the dry port life cycle, and different relations with seaport. We will provide a clear vision on the concept development and the advantages that can be added to the seaport and transportation flow. Then, the study will show the evolution of the research community interest on the concept. In the first step, we will briefly present all the challenges faced by seaports today. Next, we will undertake a systematic literature review in order to provide a global vision able to answer questions concerning dry port concept, types, research evolution. Finally, we will present some research topics that open for us at the dry port seaport system.

\section{KEY WORDS}

$\sim$ Dry port

$\sim$ Seaport

$\sim$ Multimodal transport

$\sim$ Logistic

$\sim$ Systematic literature review

$\sim$ Inland port

\author{
University of Hassan 1st, Faculty of Sscience and Technology, Morocco \\ e-mail: nabil.lamii.01@gmail.com \\ doi: 10.7225/toms.v09.n02.009
}

This work is licensed under (cc) BY

\section{INTRODUCTION}

Since the 1970s, the world has experienced an acceleration of interconnections between the different geographical zones of the world. Today it can be defined with the concept of globalisation. It summarizes all flows, capitals, information, technology and goods beyond the national level to form an interconnected global network (Hirst et al., 2009). The global economy today has broken several geographical, technological and political barriers, and gives the global supply chain the capability to be developed in a remarkable way, and to open a new dimension such as the internationalisation of industrial production. As the world has changed since 1970, the international market is becoming increasingly global because of many factors such as the positive evolution of the world economy and the internationalisation of industrial production (UNCTAD, 2018). This is subsequently reflected in the growing demand for the maritime transport services, which has also experienced an unprecedented evolution, as shown in Figure 1 (UNCTAD, 2018), by pushing the maritime transport structure to cope with the global economy (Haralambides and Gujar, 2011).

For this reason, the structure of maritime transport has gone through several transitional phases. One of the most significant phases is containerisation concept emergence, which has clearly contributed to the evolution of maritime transport (Berg and Langen, 2015).

Following the growth of the world economy, the volume of merchandise transported by sea is increasing every year (Figure 1). This can amplify the seaport challenges like the increasing difficulty of container management, lack of space, congestion at seaports access points, and negative environmental impacts. 


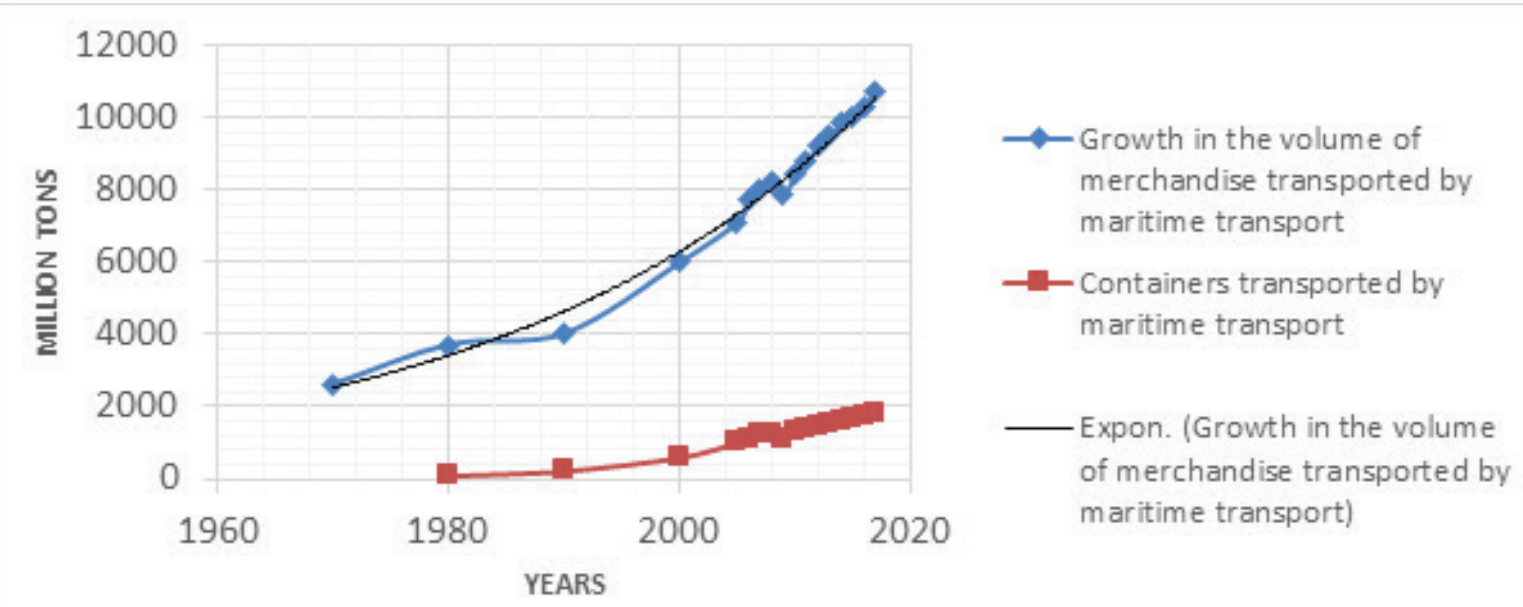

Figure 1.

Maritime transport services evolution (UNCTAD, 2018).

In the remainder of this paper, Section 2 presents an overview of seaport challenges. Dry port concept is defined in Section 3. In Section 4, we propose a systematic literature review in order to give a global vision about the concept development. The results of the research development are presented in Section 5. The concluding remarks and discussion are provided in Section 6.

\section{AN OVERVIEW OF SEAPORT CHALLENGES}

The seaport is the most important node in the international transportation chain. In general, with the growth of the world economy, the demand for the maritime transport services is increasing considerably (Figure 1), which raises challenges for the seaport.

As a result, it is normal to bring more importance on seaport evolution which becomes more and more critical (Mabrouki et al., 2014). Dry port existence has become a solution for seaport problems. Thus, dry port performance is linked to the seaport performance and with a large vision is linked to the dry portseaport system (Bentaleb et al., 2015a).

In other words, the understanding of the seaport challenges leads us to recognise the dry port necessity and functioning. In Table 1, the most important seaport challenges are listed.

The critical role that seaport plays in the global supply chain requires an adequate solution to optimize the performance of its services in order to overcome these challenges (Table 1). Dry port can improve significantly the performance of the seaport. Therefore, the performance of the dry port seaport system raises
(Bentaleb et al., 2015a). Consequently, in order to increase seaport performance, we need to develop more the dry port concept. It represents an intermodal terminal directly connected to the seaport, with high-capacity means of transport, where customers can leave/pick up their goods as if heading directly to a seaport (Roso et al., 2009; Wiegmans et al., 2015). This gives us a relevant solution for optimising seaport services and transforming it to a more efficient system such as the seaport dry port system.

The main purpose of this systematic literature review is to have a global vision of the dry port concept, and its advantages that can increase the efficiency of the seaport services and the whole transportation chain. We propose to achieve this objective by answering the following questions:

- What are the existing definitions of dry port concept?

- How has the dry port concept evolved over time?

- What are the functions and actors of dry port?

- What are the advantages provided by the seaport dry port system?

- How has the research on the concept of dry port developed?

- What are the methods that research focuses on when it deals with the dry port concept?

- Which countries are interested in the dry port concept and how?

- What are the journals and authors interested in the concept of the dry port?

Answering these questions will allow a deep understanding of e.g. dry port concept, role, functions, importance, interactions, and stakeholders. 
Table 1.

The most significant seaport challenges.

\begin{tabular}{|c|c|}
\hline Seaport challenges & Causes \\
\hline $\begin{array}{l}\text { The difficulties of } \\
\text { managing goods today }\end{array}$ & $\begin{array}{l}\text { - The growth of the world economy (Hirst et al., 2009). } \\
\text { - The evolution of maritime traffic (UNCTAD, 2018). }\end{array}$ \\
\hline Lack of space & $\begin{array}{l}\text { - The steady increase in the volume of merchandise trade (UNCTAD, 2018). } \\
\text { - The increase in containerisation and its negative effects such as the increase of the containers' number } \\
\text { in distress (Berg and Langen, 2015; UNCTAD, 2018). } \\
\text { - Urban growth at the entourage of seaports, which prevents seaport expansion. (Hanaoka and Regmi, } \\
\text { 2011) } \\
\text {-The different types of goods handled add their effect on the layout: The separation of different types of } \\
\text { goods for safety purposes (dangerous goods and zones without dangerous goods), reefer containers, } \\
\text { etc. (Santarremigia et al., 2018) } \\
\text {-The higher these types of goods in a terminal, the lower are the space for other goods: containers with } \\
\text { dangerous goods cannot be stacked as high as non-dangerous containers, and the same happens with } \\
\text { empty containers. (Hervás-Peralta et al., 2019) }\end{array}$ \\
\hline $\begin{array}{l}\text { Congestion at seaport } \\
\text { access at trucks' entrance }\end{array}$ & $\begin{array}{l}\text { - The large number of containers accommodated and shipped at the same time. (Bentaleb et al., 2015b) } \\
\text { - Loading and unloading time. } \\
\text { - The insufficient number of access routes to the terminal service of certain seaports. }\end{array}$ \\
\hline
\end{tabular}

The increase of transport Non-optimal management of transport flows between seaports and shippers (Lättilä et al., 2013). costs

Negative environmental The high number of trucks that have a negative environmental impact. (Lättilä et al., 2013; Li et al., impact 2019; Roso, 2007).

\section{DRY PORT CONCEPT}

\subsection{Definitions}

Since the appearance of the dry port concept, researchers have mentioned several definitions with small differences that developed over time. It is e.g. the type of connection between dry port and seaport. Woxenius et al. (2004) in their definition claim the rail as the only type of connection between seaport and dry port. However, Jaržemskis and Vasiliauskas (2007) added the road as a connection in their definition. Then, Witte et al. (2019) used the waterway as a possible type of connection. Table 2 summarises the most cited definitions.

The past period of research on the dry port topic definitions have shown that the concept is visibly much more fertile than we expect.

Table 2.

The most cited definitions of dry port concept.

\begin{tabular}{llll} 
Source & Year & Definitions & Determinants \\
\hline (UNCTAD, 1991) & 1991 & $\begin{array}{l}\text { Dry port is located near inland from seaports. It is linked } \\
\text { directly to seaport or, in the case of international land } \\
\text { movement, is in contact with the sources of imports and } \\
\text { destination of exports. Dry ports may be used either in a } \\
\text { country that has seaports or in landlocked country, but only } \\
\text { surface transport modes are involved in giving access to dry } \\
\text { port. }\end{array}$ & $\begin{array}{l}\text { Connected to seaport by } \\
\text { surface transport modes. }\end{array}$ \\
& & $\begin{array}{l}\text { The dry port concept is based on a seaport directly connected } \\
\text { with inland intermodal terminals by rail where goods in } \\
\text { intermodal loading units can be turned in as if directly to the }\end{array}$ & Connected to seaport \\
(Woxincipally by rail. &
\end{tabular}




\begin{tabular}{|c|c|c|c|}
\hline $\begin{array}{l}\text { (Jaržemskis and } \\
\text { Vasiliauskas, 2007) }\end{array}$ & 2007 & $\begin{array}{l}\text { A dry port is a port situated in the hinterland servicing } \\
\text { an industrial/commercial region connected with one or } \\
\text { several seaports by rail and/or road transport and is offering } \\
\text { specialized services between the dry port and the transmarine } \\
\text { destinations. Normally the dry port is containers and } \\
\text { multimodal oriented and has all logistics facilities, which is } \\
\text { needed for shipping and forwarding agents in a port. }\end{array}$ & $\begin{array}{l}\text { Connected to seaport by rail } \\
\text { and/or road transport and is } \\
\text { offering specialized services. }\end{array}$ \\
\hline (Roso et al., 2009) & 2009 & $\begin{array}{l}\text { The dry port concept is based on a seaport directly connected } \\
\text { by rail to inland intermodal terminals, where shippers can } \\
\text { leave and/or collect their standardized units as if directly at the } \\
\text { seaport. }\end{array}$ & $\begin{array}{l}\text { Connected to seaport by rail } \\
\text { and is offering same services } \\
\text { as seaport. }\end{array}$ \\
\hline (Ng and Girish, 2009) & 2009 & $\begin{array}{l}\text { Dry port can be understood as an inland setting with cargo- } \\
\text { handling facilities to allow several functions to carry out, for } \\
\text { example, cargo consolidation and distribution, temporary } \\
\text { storage of containers, custom clearance, connection between } \\
\text { different transport modes, allowing agglomeration of } \\
\text { institutions (both private and public) which facilitates the } \\
\text { interactions between different stakeholders along the supply } \\
\text { chain, etc. }\end{array}$ & $\begin{array}{l}\text { Connected to seaport by } \\
\text { different transport modes, } \\
\text { allowing agglomeration of } \\
\text { institutions both private and } \\
\text { public. }\end{array}$ \\
\hline (Witte et al., 2019) & 2019 & $\begin{array}{l}\text { Inland ports or dry ports is an inland facility with or without an } \\
\text { intermodal terminal and logistics companies, which is directly } \\
\text { connected to the seaport(s) with high capacity transport mean } \\
\text { (s) either via rail, road or inland waterways, where customers } \\
\text { can leave/pick up their standardized units as if directly to a } \\
\text { seaport }\end{array}$ & $\begin{array}{l}\text { Connected to seaport by rail, } \\
\text { road or inland waterways, } \\
\text { same services as seaport. }\end{array}$ \\
\hline
\end{tabular}

Table 3.

Dry port advantages.

\begin{tabular}{|c|c|}
\hline & Advantages of dry port \\
\hline Seaport & $\begin{array}{l}\text { Reduce congestion at access points; } \\
\text { Facilitate inventory management; } \\
\text { Positive influence on the cost of storage; } \\
\text { Increase the storage capacity of goods; } \\
\text { Facilitate and increase the speed of services. }\end{array}$ \\
\hline City & Reduction of traffic congestion. \\
\hline Environment & $\begin{array}{l}\text { Reduction of influence of } \mathrm{CO} 2 \text { caused by } \\
\text { emissions from trucks. }\end{array}$ \\
\hline Shippers & $\begin{array}{l}\text { Reduce transportation cost; } \\
\text { Reduce storage cost; } \\
\text { Facilitate access to seaports. }\end{array}$ \\
\hline $\begin{array}{l}\text { Country } \\
\text { (society) }\end{array}$ & $\begin{array}{l}\text { Develop commercial transport flows; } \\
\text { More benefits for landlocked countries; } \\
\text { More jobs in areas near the dry port. }\end{array}$ \\
\hline $\begin{array}{l}\text { Rail way } \\
\text { companies }\end{array}$ & Diversification of the commercial offer. \\
\hline
\end{tabular}

\subsection{Dry Port Roles}

The establishment of the dry port brings a number of advantages to the seaport performance and touches upon other aspects. Table 3 sheds light on the advantages of the dry port.

As an option to decrease congestion, seaport challenges, and reduction in transportation cost, dry ports have a key role to play in advancing seaport connectivity.

\subsection{Dry Port Functions}

In general, the dry port functions are similar to the seaport except for the connection with the sea. They are replaced with other functions related to other transport means, essentially railway, but sometimes waterway or road are also considered. Figure 2 presents the major dry port functions.

According to Crainic et al. (2015), dry port can assume three main types within the transport chain: satellite terminal, load centre, and transhipment facility. In order for the seaport to function successfully, it is required to develop not only the seaport infrastructure, but also dry port functions. 


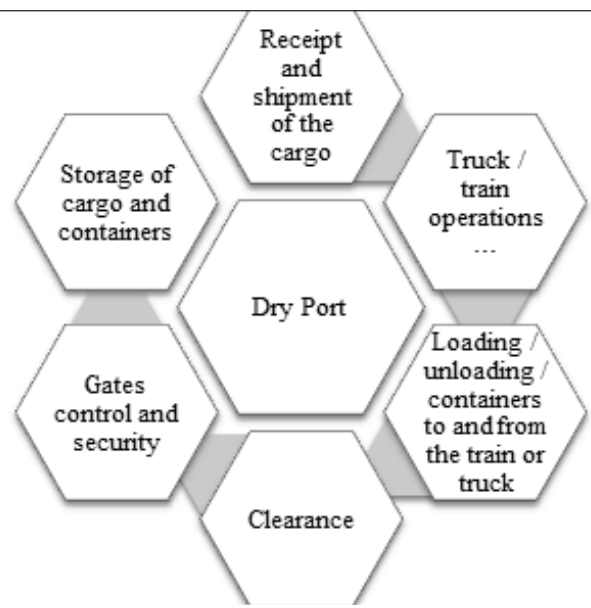

Figure 2.

Dry port functions (Hayut, 1980; Notteboom and Rodrigue, 2009; UNCTAD, 1991).

\subsection{Dry Port Types}

The research community distinguishes between three types of dry ports based on the distance between seaport and dry port. Thus, they are named close dry port, mid-range dry port, and distant dry port (Figure 3).

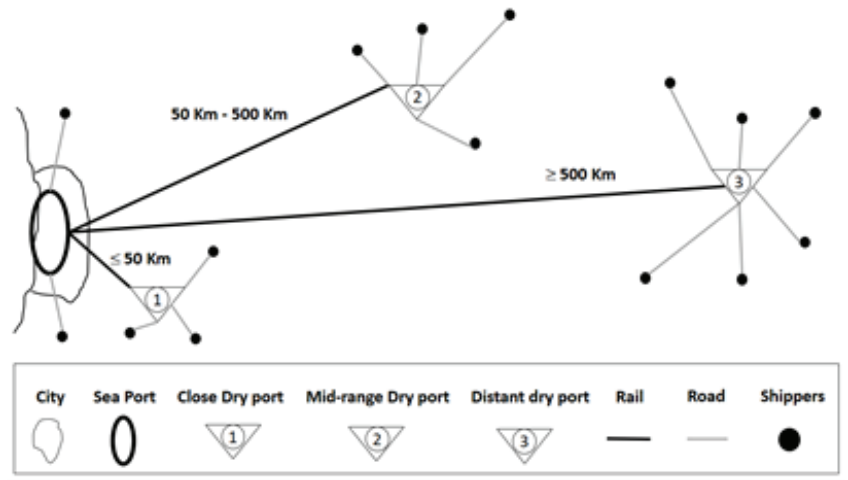

Figure 3.

Dry port types (Bask et al., 2014; Roso et al., 2009).

Each type has its own characteristics. Table 4 explains the particularities and the advantages (Crainic et al., 2015; Tsao and Thanh, 2019; Woxenius et al., 2004).

There are different dry port types that correspond to different seaport configurations. Hence, different types of dry port have been developed in different regions (Rodrigue and Notteboom, 2012; Santarremigia et al., 2018). The types of dry ports play an essential role in the development process. As shown in Table 4, there are a number of competitive advantages that dry ports can supply to maintain seaport development.

Table 4.

Dry port type particularities.

\section{Type}

Distant dry port

\section{Distance to seaport Advantages}

\section{More than $500 \quad$ Transhipment}

kilometres $\quad$-Transport over long distance;

-Reduce traffic congestion (Roso et al., 2009);

-The distance factor plays a remarkable role on reducing the transportation costs and the negative impact on the environment. (Bask et al., 2014; Crainic et al., 2015; Roso et al., 2009; Tsao and Thanh, 2019; Woxenius et al., 2004)

Mid-range dry port Between 50 and 500 Load centre

kilometres $\quad$-Reduce transportation costs (Roso et al., 2009),

-Reduce traffic congestion;

-Have positive environmental impact.

-Represent effective point for consolidation (Tsao and Thanh, 2019; Woxenius et al. 2004)

Close dry port $\quad$ Less than 50

Satellite terminal

- Offer large storage space for seaports;(Bask et al., 2014; Crainic et al., 2015; Tsao and Thanh, 2019)

- Offer greater possibilities for buffering containers around seaport to reduce local traffic (Bask et al., 2014; Tsao and Thanh, 2019)

-Offer consolidation of transport flow to and from seaport. (Crainic et al., 2015) 


\subsection{Dry Port Life Cycle Development}

In the earliest research on the dry port seaport system, the first mention of a graphic modelling of the system was in 2011, when Wilmsmeier et al. (2011) presented a model that clarifies the spatial evolution of the relation structure between the dry

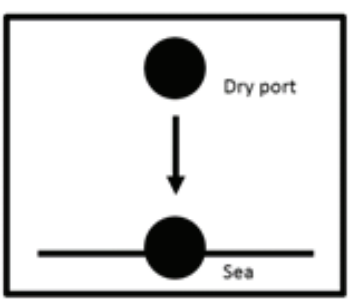

Inside - Out

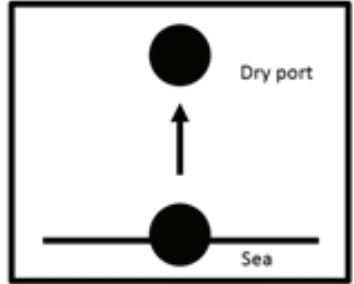

Outside - In
Figure 4.

Wilmsmeier et al. (2011) model. port and the seaport (Figure 4). This model presents two types of connections. The inside-out development begins from the dry port, and the outside-in development starts from the seaport.

In addition, Bask et al. (2014) linked the model of Wilmsmeier et al. (2011) with the time factor in order to give a model of three phases: 1) Pre-phase, 2) Start-up phase, and 3) Growth phase, as shown in Figure 5.

Pre-phase is the phase of the dry port creation, where several basic questions arise, e.g. Is the existence of the dry port important? Is there a robust infrastructure and strategy that supports the creation of the dry port?

Start-up phase is the opening. It is the first step in the implementation of the dry port plans. At this stage, the actors involved discuss the execution process and the investment on the direction development.

Growth phases is the development of the dry port in an operational direction, e.g. the introduction of a diversity addedvalue activities and the increase of relations between the actors involved.

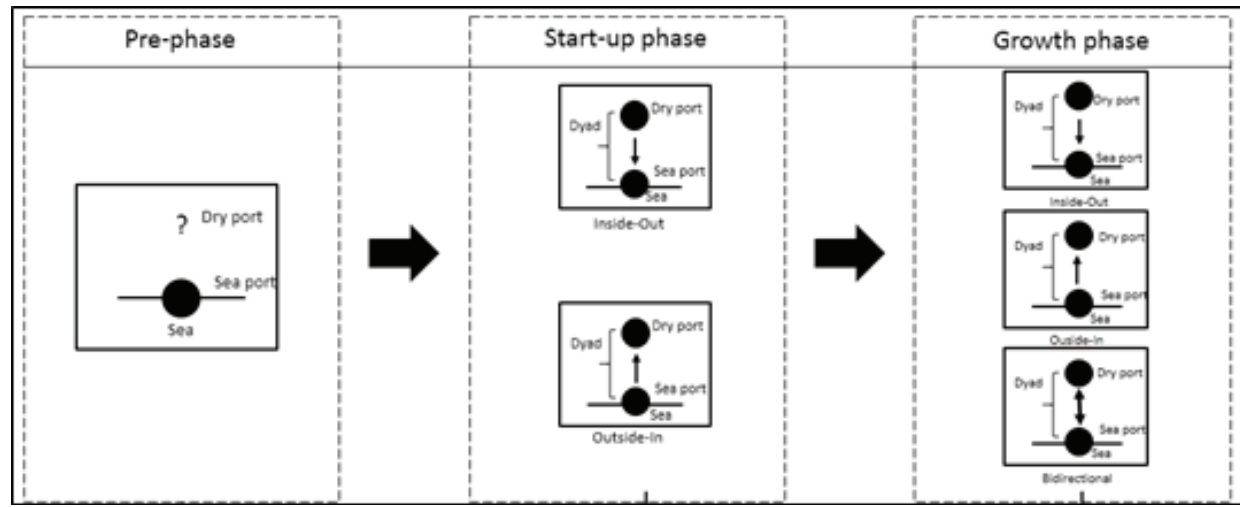

Figure 5.

Bask et al. (2014) model.

In 2016, Bentaleb et al. (2016) apply the Vernon (1966) theory of product life cycle to the dry port-seaport system, which involves a description of its phases as follows:

Development phase: The recognition of dry port in the transportation structure is prepared. The first questions asked at this stage are about the necessity of the dry port. The managers of the dry port put together an implementation plan. The plan should define the targets and goals of the dry port over the short, intermediate, and long term.

Introduction phase: The introduction of a dry port position in the transport system with some services is finished. Activities are elementary. The geographic reach is limited to the adjacent city.

Growth phase: The dry port's services increase. Standardisation and process innovation are addressed and implemented. The dedicated regions of the dry ports increase. Dry port develops in the operational direction.

Maturity phase: The dry port activity increases at a slower rate. Competition in the market augments as the number of dry ports augments. The external competition increases simultaneously and in proportion with increased maturity. This phase includes three sub-phases, i.e.:

Sub-phase (4.1): inside-out or outside-in (the case of one seaport with many dry ports). In this sub-phase, we witness the start of limited connections between the seaport and other dry ports, which represents a spatial development of one seaport with several dry ports.

Sub-phase (4.2): bidirectional development (the case of one seaport with many dry ports). This sub-phase represents the operational development direction of one seaport with many 


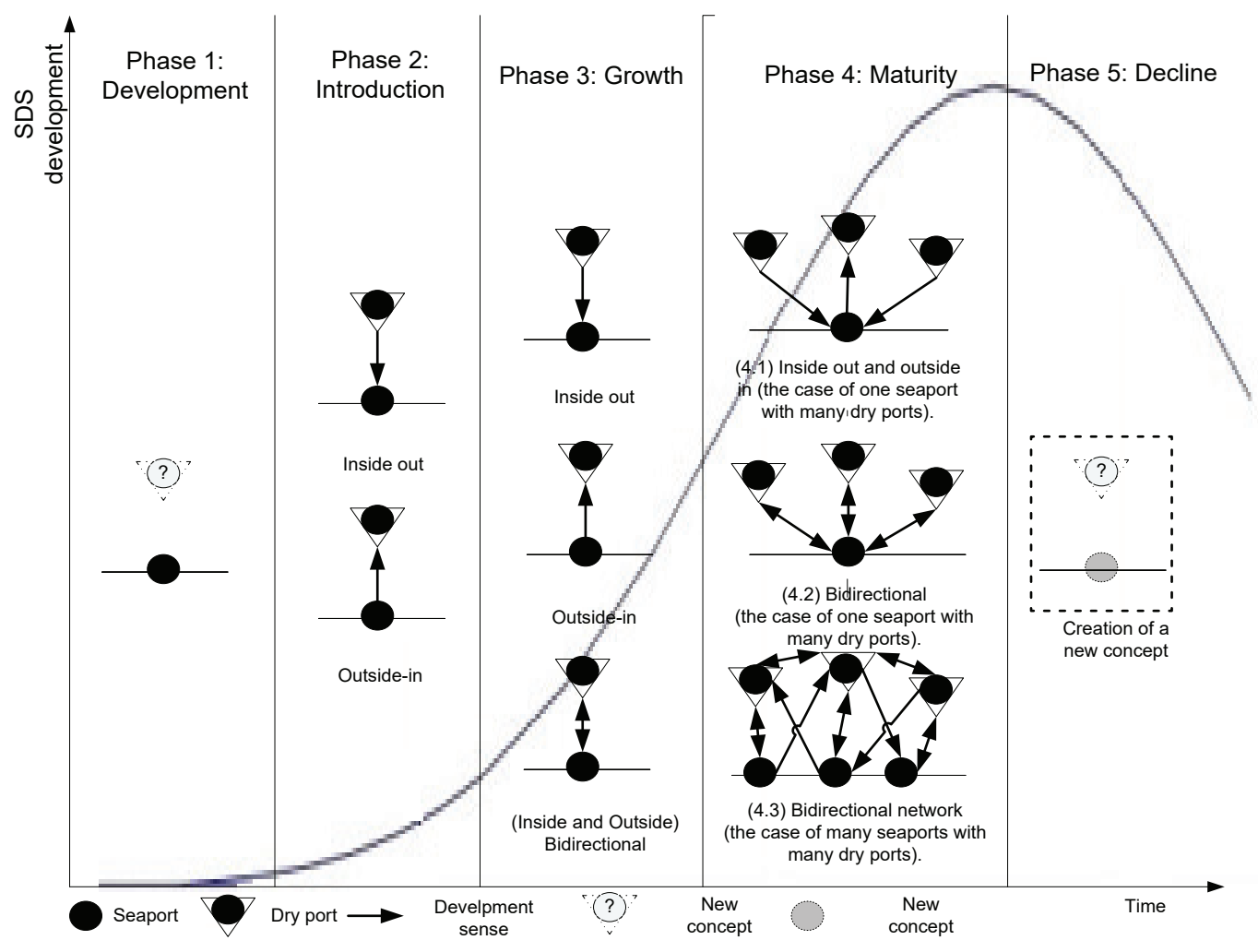

Figure 6.

Bentaleb et al. (2016) model.

dry ports, such as the development of a variety of added-value services, which makes the connection between seaport and the other dry ports more efficient.

Sub-phase (4.3): bidirectional network (i.e. the case of many seaports with many dry ports). This sub-phase represents the operational development direction of many seaports with many dry ports.

Decline phase: This happens eventually when we arrive to the point of the limitations in feasible rationalization or when the improvement process in general is achieved.

In this phase, we can announce the decline of this system, and maybe a new concept will be created, which could be a direction of future research.

The life cycle of the dry port concept will help to make the research more comprehensive. However, as shown above, our literature research is still based on individual case studies. It is essential to conceptualise the progress of the dry port in a more systematic approach. Therefore, this review paper shows a systematic review of journal papers on the dry port progress between 1980 and 2020. We try to organise the concept of the dry port on different investigative levels.

\section{SYSTEMATIC LITERATURE REVIEW}

Dry port development has had additional consideration by researchers and academics all over the world. A systematic review by Bentaleb et al. (2015a) of the dry port development between 1986 and 2015 revealed that there is a lack of studies relating literature review of the dry port concept. We followed a process of seven steps (Figure 7). This facilitates the analysis of the review and provides possible answers to the questions.

\section{- $\quad$ Step 1: Establishment of the time period}

In this step, we chose a time interval that starts from 1980 to 2020. The reason behind this choice is to have a more global vision on the concept of dry port, and because of the fact that before 1980 we did not find articles clearly related to the dry port concept.

\section{- $\quad$ Step 2: Definition of the keywords}

Here we chose three keywords, i.e. Dry Port, Inland Port, and Inland Intermodal Terminal, which define the same concept. Since each author uses one of these keywords to describe the concept of the dry port, we chose these three words to globalize research and increase the number of articles collected. 


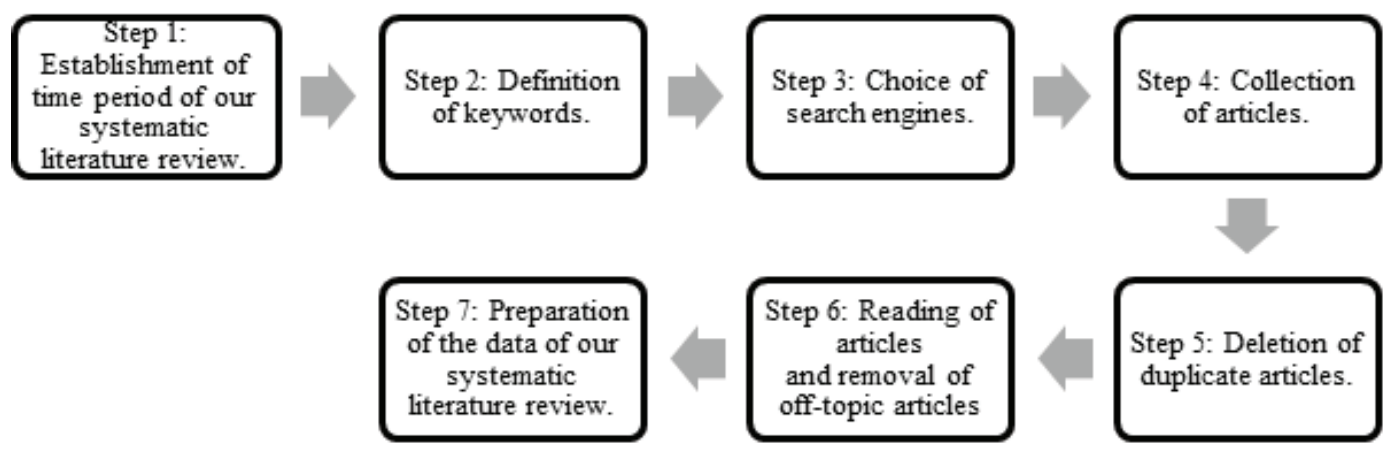

Figure 7.

Systematic literature review process.

\section{- $\quad$ Step 3: Choice of search engines}

The choice of search engines in the literature review remains as a very important step. In our case, we chose seven engines, i.e. Web of Science, Science direct, Google Scholar, IEEE Explore, Taylor \& Francis, Jstor and Springer link, to expand the research scope of the literature review.

\section{- $\quad$ Step 4: Collection of articles (674 articles)}

In this step, we started the collection of articles with two conditions. The first condition was that the document was a qualified journal article or a chapter (we did not include conference paper), and the second condition was that the title and the abstract of the document collected should be linked with one of the three chosen keywords.

When we typed a keyword in the search engines, each search engine displayed a certain number of results found in a limited number of pages. Table 5 presents the number of articles collected in each search engine whose titles and their abstracts directly related to the concept of the dry port, to arrive at a total of 674 documents collected.

\section{- Step 5: Deletion of duplicate articles (297 remained articles)}

The keywords used (Dry Port, Inland Port, Inland Intermodal Terminal) are very similar, which justifies the high number of duplicate articles of the total number of documents collected. Therefore, in this step we deleted the duplicate articles.

\section{- Step 6: Article reading and removal of the off-topic articles (125 removed articles)}

This step required accurate reading of each document to eliminate off-topic articles.

\section{- Step 7: Preparation of data on systematic literature review (172 retained articles)}

This step represents the final phase of the data structuring process. It facilitates the analysis of the data, and provides the most important information about it. Due to this step, we can have a global idea about the dry port concept and answer the above mentioned questions easily.
Table 5.

Number of articles collected in each search engine.

\begin{tabular}{|c|c|c|}
\hline Key Words & Search engines & Articles collected \\
\hline \multirow[t]{7}{*}{ Dry Port } & Science direct & 52 articles \\
\hline & Google scholar & 97 articles \\
\hline & IEEE & 1 articles \\
\hline & Taylor and Francis & 20 articles \\
\hline & Springer & 10 articles \\
\hline & Jstor & 4 articles \\
\hline & Web of Science & 98 articles \\
\hline \multirow{7}{*}{$\begin{array}{l}\text { Inland intermodal } \\
\text { terminal }\end{array}$} & Science direct & 31 articles \\
\hline & Google scholar & 73 articles \\
\hline & IEEE & 4 articles \\
\hline & Taylor and Francis & 10 articles \\
\hline & Springer & 12 articles \\
\hline & Jstor & 2 articles \\
\hline & Web of Science & 18 article \\
\hline \multirow[t]{7}{*}{ Inland port } & Science direct & 35 articles \\
\hline & Google scholar & 134 articles \\
\hline & IEEE & 1 articles \\
\hline & Taylor and Francis & 13 articles \\
\hline & Springer & 6 articles \\
\hline & Jstor & 3 articles \\
\hline & Web of Science & 51 articles \\
\hline Total: & & 674 \\
\hline
\end{tabular}




\section{REVIEW ANALYSIS}

\subsection{Research Evolution}

The goal of this section is to understand the evolution and to study tendency research about the dry port concept within the researchers' community. Consequently, based on the publication evolution of the selected papers, we can distinguish three major phases (Figure 8). Due to the limited number of published articles, we determine the first phase between 1980 and 2003. In this first phase, the treatment of the dry port concept is modest; we can explain this reticence by a lack of necessity of the dry port role. The second phase is between 2004 and 2010. It represents a remarkable point of evolution. The number of articles starts to increase clearly due to the increase in interest for the dry port role. Finally, the third phase is from 2011 until 2019. In this stage, the production of the articles related to the dry port concept significantly increases.

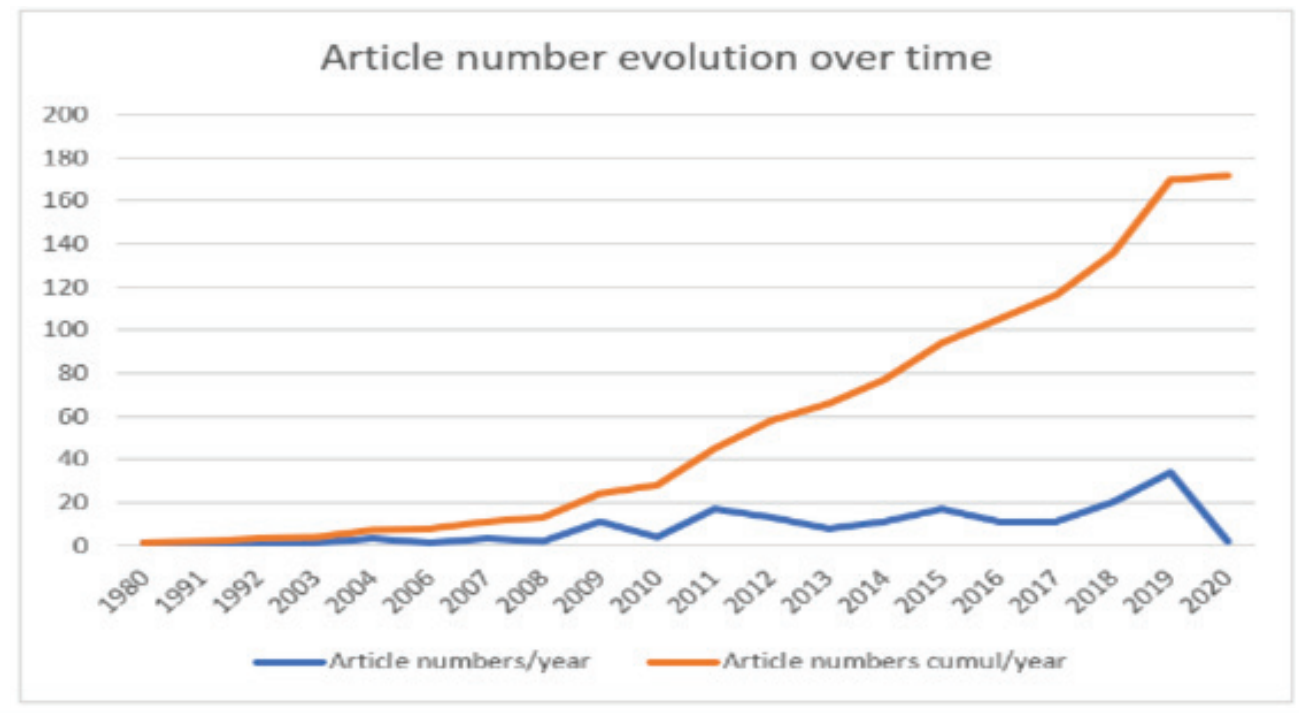

Figure 8.

Evolution of articles' number over time.

We can interpret this result by saying that the concept of the dry port becomes more important each year (Do et al., 2011; Witte et al., 2019). It shows that each year the researchers gain knowledge of the importance of the dry port concept and how it represents a perfect solution of seaport problems.

\subsection{Dry Port Research Themes Evolution}

We made a classification of the selected articles according to eight topics (see Table 6). These topics came as results of brainstorming done by our research team in order to establish

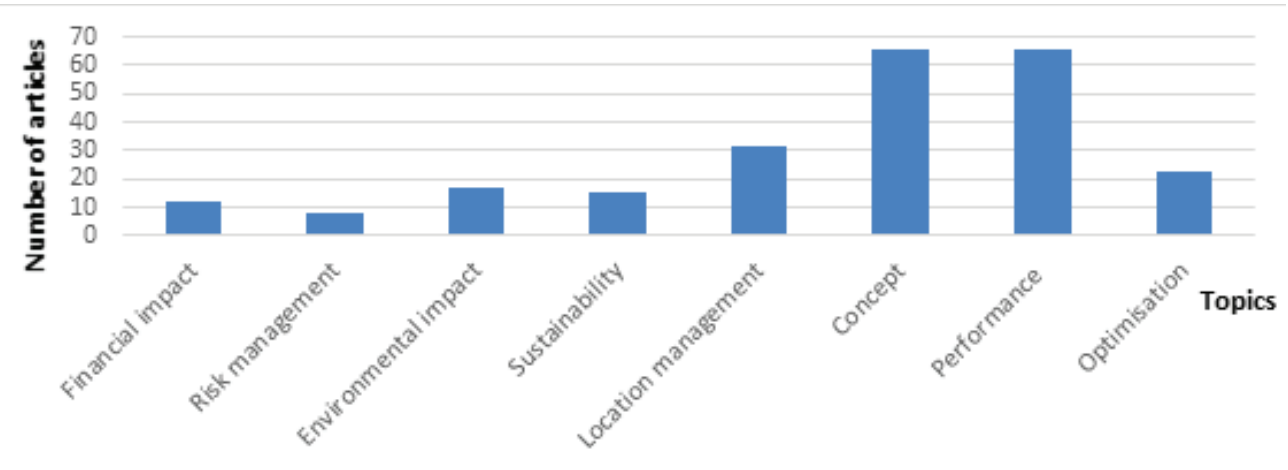

Figure 9.

Number of articles' classification according to different research topics. 
the most important topics that we could find in our systematic literature review to reinforce our future research on seaport dry port system.

The point from this classification is to have a vision on the most important topics or themes assessed in the dry port papers. We found that optimization, performance, concept, location management, sustainability, environmental impact, risk management, and financial impact are the most important topics in the systematic literature review.

Moreover, we can note that sometimes we found many themes in the same article.

However, as Figure 9 shows, the majority of the articles cover two topics, concept and performance of the dry port. That is due to the concept novelty, which explains some differences in the definitions of the dry port concept. In addition, researchers try to understand better the dry port performance and its impact.

In the articles that assess location management, we found that most of the criteria used are economic criteria, which focus primarily on the reduction of the cost of transport. Environmental criteria mainly deal with the positive impact of installing a dry port. Geographical or spatial criteria focus on the geographical accessibility and limitation. Social criteria assess the availability and skill level of the workforce, the policy that focuses on the policy of the country related to the chosen place and other criteria that change according to the context assessed in the article (Awad-Núñez et al., 2016; Bentaleb et al., 2016; Komchornrit, 2017; Nguyen and Notteboom, 2016; Roso et al., 2015, 2015). Because of the multiple criteria of the location management problem, we noticed that most articles treated the location management of the dry port using hybrid approaches based on MCDM (multi-criteria decision making) methods like AHP, ELECTRE, Fuzzy ANP or MACBETH (Abdoulkarim et al., 2019; Bentaleb et al., 2016; Ka, 2011; Komchornrit, 2017; Roso et al., 2015; Wei et al., 2010).

Subsequently, we realized the time projection of the themes, which gave us a vision on the temporal progress of each theme in the systematic literature review. Figure 10 shows the evolution of articles about the dry port concept over time and their domain of studies. However, after the year 2010, the number of articles that touch the performance aspect increased in a remarkable way. It could be explained by changing the research angle of vision. In the beginning, research treated the concept in a general way; then, we noticed a development of the topics treating other aspects of the dry port concept over time, e.g. dry port performance.

The main reason behind this development is that at first the concept was ambiguous and unknown. However, over time the importance of the dry port has become more interesting for the researchers, who revealed other themes of research, e.g. performance, in Bentaleb et al. (2015a), Li and Jiang (2014); location management, in Bentaleb et al. (2016), Ka (2011), Nguyen and Notteboom (2016); life cycle, in Bask et al. (2014), Wang (2014); risk management, in Bentaleb et al.( 2015b), Gong and Liu (2020).

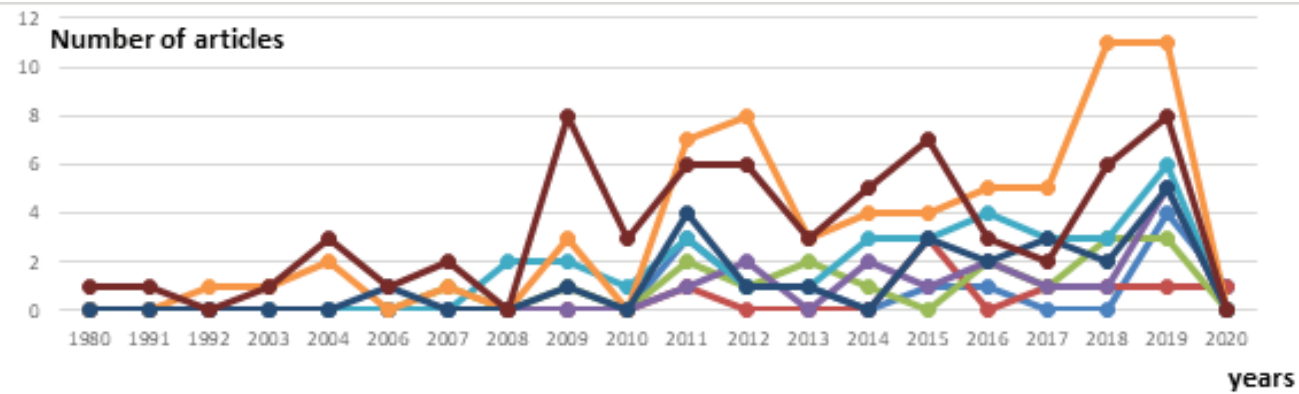

Figure 10.

Evolution of papers' number on dry port theme over time.

\subsection{Dry Port Research Methods' Evolution}

In this section, a classification is made according to eight sets of methods (Table 6). Each set represents a category of methods used. The goal is to clarify the methods used by the authors of the selected articles.

The eight sets of methods are: 
Table 6.

Eight sets of methods used in dry port articles.

\begin{tabular}{llll} 
Sets & Set description & Methods or types & Papers number \\
\hline A & $\begin{array}{l}\text { Articles dedicated entirely to literature review (4 Articles) } \\
\text { Articles contain sections of literature review or about reviews (69 } \\
\text { Articles). }\end{array}$ & $\begin{array}{l}\text { Literature reviews and } \\
\text { previews. }\end{array}$ & 73 \\
\hline B & $\begin{array}{l}\text { Case studies, where the treatment focused on a certain dry port, } \\
\text { region or a precise country. }\end{array}$ & Case studies. & 143 \\
\hline C & Articles using graphic modelling methods. & Graphic modelling. & 10 \\
\hline D & Studies based on interviews or/and survey. & Interviews and survey & 58 \\
\hline E & Articles that use mathematical modelling or optimization methods. & Mathematical models. & 71 \\
\hline F & $\begin{array}{l}\text { Studies based on the database, reports or archives. } \\
\text { G }\end{array}$ & $\begin{array}{l}\text { Articles based on computer software, numerical analysis or computer } \\
\text { languages. For example, Cortés et al. (2007) present a simulation using } \\
\text { Arena software in order to simulate the inland port of Seville; Henttu et } \\
\text { al. (2011) used an optimisation software CPLEX in their research on the } \\
\text { optimal impact of dry port on environment, etc. }\end{array}$ & $\begin{array}{l}\text { Computer languages and } \\
\text { computer software }\end{array}$ \\
\hline
\end{tabular}

In this section, we made a time projection (Figure 11) of the method sets (Table 6). The point is to have a clear idea about the used methods' evolution. Moreover, as we can notice in Figure 11 , most researchers relate their articles to some region, country or a precise dry port (set B) in order to give their research certain legitimacy which makes the set $B$ the most dominant set over all the period of the systematic literature review.

In 2009, the sets of reviews and previews (A) using interviews/questionnaires (D) and databases, archives or reports (F) rank as the most used methods after the set of case studies (B). Then, the other sets of mathematical methods (E), computer software or computer languages (G), Graphic modelling (C), and the set of methods like SWOT/ benchmarking... (H) started to increase over time.

We can explain this order by the nature of development of the topics in Figure 10. In order to provide a clarification of the concept of the dry port, we return to literature review and archives. If we want to deal with the performance of the dry port or any other theme, interviews, mathematical methods, and other methods like SWOT, graphic modelling, etc. are used.

One of the most important findings that we noticed through our systematic literature review is the existence of four articles entirely dedicated to the dry port literature review (Roso and Lumsden, 2010; Bentaleb et al., 2015c; Rožić et al., 2016; Witte et al., 2019). Each article gives us a different angle of view on the dry port concept (Table 7) starting in 2010 with Roso and Lumsden (2010). They present a literature review that gives us a clear vision of the concept of the dry port and the world's existing dry ports, which represents a good opportunity for any new practitioner or researcher who wants to start discovering the dry port concept. Then, in 2015, Bentaleb et al. (2015c) give us a systematic literature review based on five steps: 1) problem definition; 2) selection of journals based on the time period between 1986 and 2015, taking in consideration four research engines (Jstor, Sciencedirect, Scopus and Google Scholar); 3) selection of studies; 4) critical evaluation, and 5) synthesis that treats the concept of dry port. The most important points of this systematic literature review are the detailed description of the development of the decision level and an illustration of all the countries where researchers were interested in the dry port concept. Furthermore, in 2016, Rožić et al. (2016) focuse on four pillars in their literature review: 1) the development of the dry port concept; 2) classification and function type of the dry port and the functions that can add value to seaports; 3 ) technological processes that represent the activities at the terminal, which are conducted with the aim of better quality of cargo handling, and which require appropriate technological elements and real-time work; 4) location determination of inland terminals presenting some methods and criteria used to determine the location of inland terminals. Finally, Witte et al. (2019) present a systematic literature review based on four steps: 1) They define the criteria for inclusion or exclusion of papers; 2) They made a systematic search of the scientific literature based on criteria determined; 3) They analysed the papers and retrieved the relevant information for the review; 4) They performed data analysis and synthesis. The most important points mentioned are: papers published across journals over time; a good view made on the papers published over time; papers by geographical focus over time, where they 


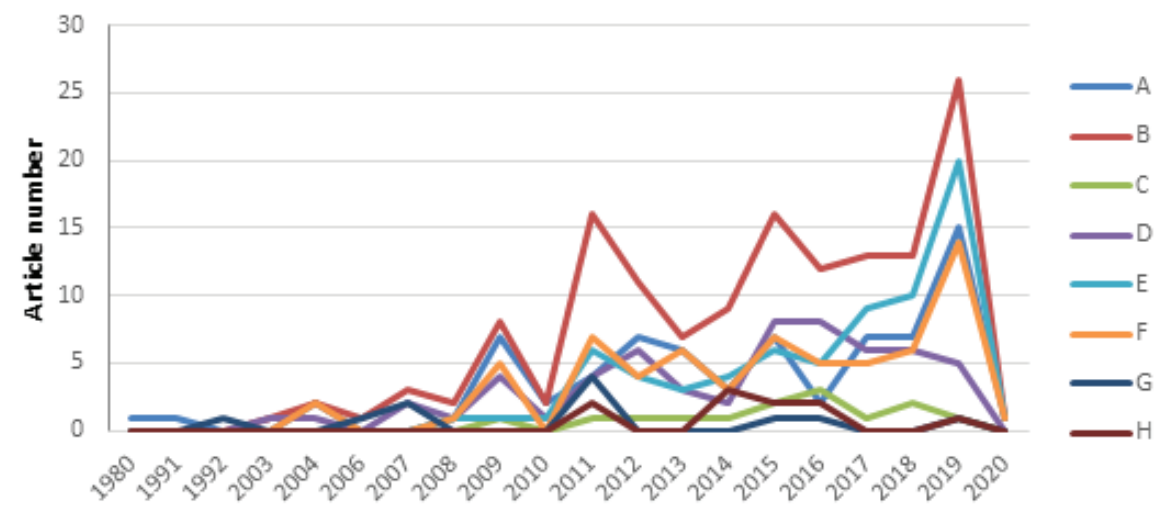

Figure 11.

Methods used evolution over time.

give us an idea about geographical focus; papers by type of methodology over time, dividing the methodology types into six categories: case study, conceptual study, quantitative (modelling), quantitative (empirical), literature reviews and editorials; papers by type of definitions over time; 5) key authors and network collaborations, where they mention most authors contributing in the dry port research; 6) key themes and conceptual approaches over time, where they present tree major periods crossed with four main conceptual approaches globalization/supply chain, port regionalisation, directional development, and institutional governance.

Table 7.

Dry port literature reviews.

\begin{tabular}{|c|c|c|c|c|c|c|}
\hline $\begin{array}{l}\text { Literature } \\
\text { reviews }\end{array}$ & Date & $\begin{array}{l}\text { Period } \\
\text { time }\end{array}$ & $\begin{array}{l}\text { Systematic } \\
\text { (yes or no) }\end{array}$ & Research methodology & Research engines & $\begin{array}{l}\text { Number } \\
\text { of articles } \\
\text { studied }\end{array}$ \\
\hline $\begin{array}{l}\text { Roso and } \\
\text { Lumsden } \\
(2010)\end{array}$ & 2010 & $\begin{array}{l}\text { Not } \\
\text { specified }\end{array}$ & no & $\begin{array}{l}\text { 1) List of dry ports obtained from journals, } \\
\text { internet base documents, containerisation } \\
\text { International and World Cargo News. } \\
\text { 2) After identifying the list of dry ports, interview } \\
\text { starts on the dry ports, based on telephone } \\
\text { survey and questionnaires sent to emails. } \\
\text { 3) Synthesis. }\end{array}$ & Not specified & $\begin{array}{l}\text { Not } \\
\text { mentioned. }\end{array}$ \\
\hline $\begin{array}{l}\text { Bentaleb } \\
\text { et al. } \\
(2015 c)\end{array}$ & 2015 & $\begin{array}{l}1986- \\
2015\end{array}$ & yes & $\begin{array}{l}\text { 1) problem definition; } \\
\text { 2) selection of journals; } \\
\text { 3) selection of studies; } \\
\text { 4) critical evaluation; } \\
\text { 5) synthesis. }\end{array}$ & $\begin{array}{l}\text { Jstor, } \\
\text { Sciencedirect, } \\
\text { Scopus, Gooogle } \\
\text { Scholar }\end{array}$ & 109 \\
\hline $\begin{array}{l}\text { Rožić et al. } \\
\text { (2016) }\end{array}$ & 2016 & $\begin{array}{l}1980- \\
2015\end{array}$ & no & Not mentioned. & Not specified & $\begin{array}{l}\text { more than } \\
60\end{array}$ \\
\hline $\begin{array}{l}\text { Witte et al. } \\
\text { (2019) }\end{array}$ & 2019 & $\begin{array}{l}1992- \\
2017\end{array}$ & yes & $\begin{array}{l}\text { 1) Defining different selection criteria for inclusion } \\
\text { or exclusion of papers. } \\
\text { 2) A systematic search of the scientific literature } \\
\text { based on the criteria. } \\
\text { 3) Analysis of the papers and retrieval of the } \\
\text { relevant information for the review. } \\
\text { 4) Data analysis and synthesis performed. }\end{array}$ & www.scopus.com & 80 \\
\hline
\end{tabular}


However, if we take all the literature reviews found until now on the dry port concept including this paper, we will notice that there are some common points, e.g. the development of the concept of the dry port or the published papers over time.

On the other hand, all these literature reviews complement each other. Each paper gives a different view on the dry port concept: Roso and Lumsden (2010) give a good overview on the existing dry ports; Bentaleb et al. (2015c) give the decision level of the articles between 1986 and 2015, and a detailed geographical description on the dry port concept research. Rožić et al. (2016) add a detailed description of the methods and criteria used to locate the dry port. Witte et al. (2019) illustrate the key themes and conceptual approaches over time. In our paper, we try to give another vision of the themes used in the dry port research.

We add an overview of the life cycle of the dry port development and we try to optimise our systematic methodology of research. We choose our time interval between 1980 and 2019; then, we determine six research engines in order to have more articles evaluating the dry port concept. Therefore, we recommend for all future researchers or practitioners to start with these literature reviews in order to have a clear and complete vision on this interesting concept.

A literature review on the dry port concept contributes to defining the most important flows in the dry port research. Recent studies have shown that the concept is visibly more diversified and much more fertile. Still, as much of the literature is principally based on individual case studies, the research of dry ports has proven to particularly need more focus on operational aspect search, e.g. risk management, performance management, etc.

\subsection{Relation Between Topics and Methods}

In addition, a cross between the sets of methods and the topics/themes has been realised to get a clear vision of the methods used in each topic (Figure 11). This gave us a great combination in each topic/theme, e.g. in the topic of "concept" we found that the first set of methods used is B (case studies) in order to give legitimacy and realistic aspect to research in this theme. After that, the sets $A$ (literature reviews) and $F$ (return to archives) follow the set $B$ to make a connection between the past and the present in the treatment of the dry port concept. The same reasoning goes for the other themes to make a clear vision on the most used methods in each theme.

Regarding the content of the articles about the relation between topics and methods, Figure 12 shows that cases studies (Set B) are the most treated topics that evoke performance, concept and localization aspects. Furthermore, we observe an important use of methods in relation with performance, concept and localization aspects. With regard to the topic graphic modelling (set C), computer software or computer languages (set $\mathrm{G}$ ) and other analytical methods (set $\mathrm{H}$ ) have not been a priority for the research community up to now.

Therefore, most documents are case studies focusing on dry port performance, followed by studies on concepts and localisation.

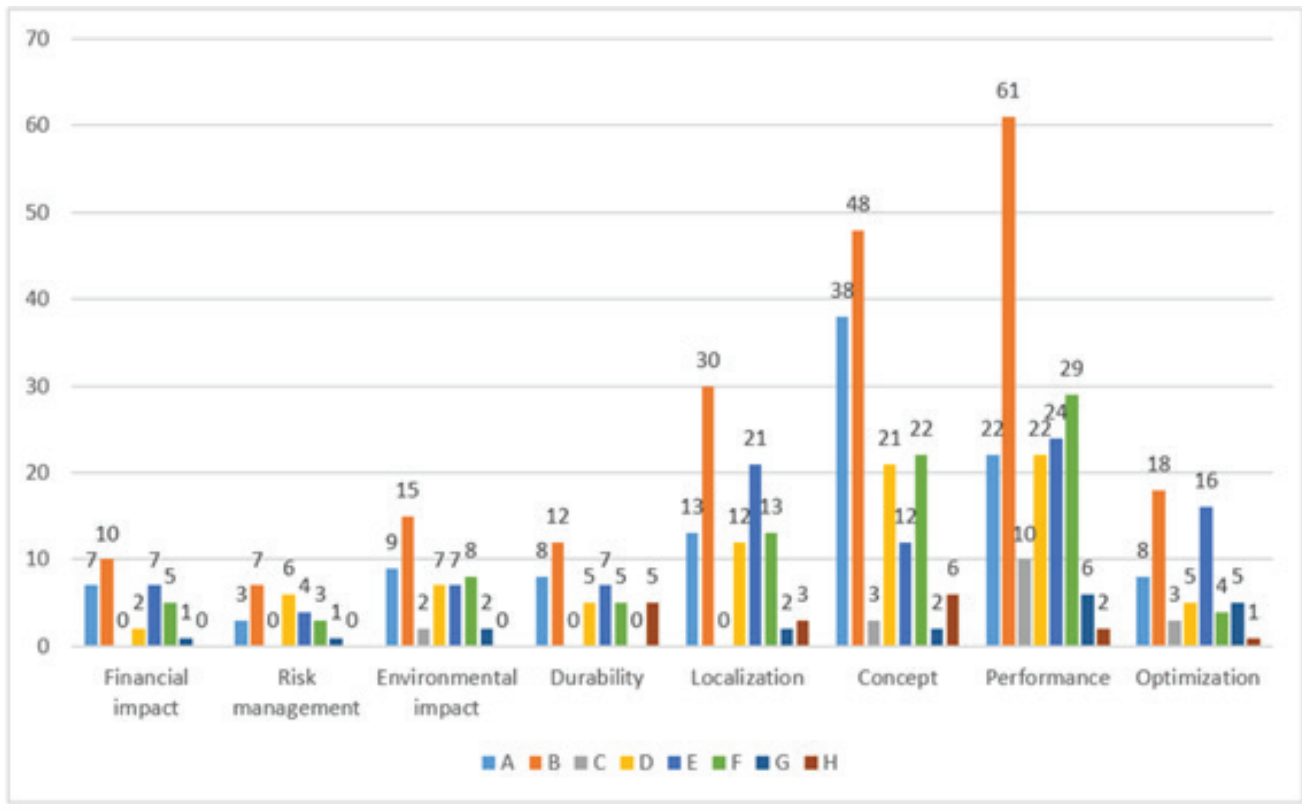

Figure 12.

Methods used in each topic 


\subsection{Dry Port Journals and Countries' Trending}

In this section, the goal is to identify the most productive journals (Table 8) and countries (Table 9) in relation with the dry port concept. We made a classification of journals and countries according to the number of articles in the systematic literature review. Table 8 shows the most relevant journals found.

This part contains the dry port documents in different countries. Different dry port types were developed in different regions and countries. We accumulate papers from a geographic angle. Table 9 shows the top 20 countries in terms of contribution in the selected documents in the systematic literature review.

Within this trend, interest for the dry port is expanding mutually across the variety of journals covered as well as geographical level. As the recognised research gaps demonstrate, more attention could be covered in terms of further practical studies on the dry port topic.
Table 8.

Journals' trending in dry port topic.

\begin{tabular}{ll} 
Journals & $\begin{array}{l}\text { Number of } \\
\text { articles }\end{array}$ \\
\hline Journal of Transport Geography & 15 \\
\hline Maritime Policy and Management & 12 \\
\hline Maritime Economics and Logistics & 9 \\
\hline Research in Transportation Economics & 9 \\
\hline Transportation Research Part E & $\mathbf{7}$ \\
\hline Research in Transportation Business and & $\mathbf{6}$ \\
Management & $\mathbf{5}$ \\
\hline Procedia - Social and Behavioral Sciences & $\mathbf{5}$ \\
\hline Sustainability & $\mathbf{5}$ \\
\hline the Asian journal of shipping and logistics & $\mathbf{4}$ \\
\hline Transportation Research Part A &
\end{tabular}

Table 9.

Top 20 countries in terms of contribution in the selected documents in the systematic literature review.

\begin{tabular}{|c|c|c|c|}
\hline Countries & $\begin{array}{l}\text { Articles with all the authors } \\
\text { from the same country }\end{array}$ & $\begin{array}{l}\text { Articles with authors from } \\
\text { different countries }\end{array}$ & Total number of articles \\
\hline China & 31 & 16 & 47 \\
\hline Sweden & 9 & 8 & 17 \\
\hline The United States of America & 7 & 9 & 16 \\
\hline The Netherlands & 8 & 7 & 15 \\
\hline United Kingdom & 4 & 10 & 14 \\
\hline Spain & 10 & 2 & 12 \\
\hline Italy & 8 & 1 & 9 \\
\hline Australia & 4 & 4 & 8 \\
\hline Belgium & 2 & 6 & 8 \\
\hline Morocco & 5 & & 5 \\
\hline Canada & 2 & 3 & 5 \\
\hline Croatia & 2 & 3 & 5 \\
\hline Finland & 3 & 2 & 5 \\
\hline Malaysia & 4 & 1 & 5 \\
\hline Chile & & 4 & 4 \\
\hline French & 2 & 2 & 4 \\
\hline Germany & 2 & 2 & 4 \\
\hline Singapore & 2 & 2 & 4 \\
\hline Czech Republic & 3 & & 3 \\
\hline India & 3 & & 3 \\
\hline Russia & 3 & & 3 \\
\hline
\end{tabular}




\section{CONCLUSION AND DISCUSSION}

Over time, the dry port concept has changed from a simple infrastructure exchange point to a real solution for the maritime transport. Dry port studies have also evolved in similar ways. In the end, we found out that the dry port seaport system has become a very interesting subject due to its important contribution in the intermodal transport and its advantages that it can add to the global supply chain management. As this paper reveals, each year the dry port is becoming increasingly attractive for researchers. This is reflected in the development of the dry port concept and the appearance of the dry port types. This evolution has generated a number of implications with regard to the dry port role and functions. The past period of research on the dry port topic definitions have shown that the concept is visibly much more fertile than we expect.

One rising and significant topic emphasised by this study concerns the investigation about dry port case studies and their relationship with the dry port performance. Therefore, this review paper shows a systematic review of journal papers on the dry port progress between 1980 and 2020 (172 considered articles). We have tried to organise the concept on different investigative levels. Based on the evolution and study tendency research as well as the publication evolution of the selected papers, we can distinguish three major phases. First, the research treats the concept in a general way; then, we note a development of topics related to other aspects of the dry port concept over time, like dry port performance. The main reason behind this development is that at first the concept was ambiguous and unknown. Still, over time the importance of the dry port has become more interesting. Within this trend, interest for the dry port as well as the geographical level is increasing mutually in a variety of journals covered. As the recognized research gaps demonstrate, more attention could be expected in terms of further practical studies on the dry port topic. However, as we notice in this paper, despite the development of research, some topics have not been considered adequately, e.g. risk management, environmental impact or the financial influence of the dry port. We notice that there are some gaps in the research about the dry port. Additionally, this article recommends researchers, academics, and professionals to focus more research on the dry port, opening some opportunities for future research on the dry port concept. Finally, it is also essential to present some limitations of this systematic review. A major aspect is the concentration of studies in journals without inclusion of conference papers.

\section{REFERENCES}

Abdoulkarim, H.T., Fatouma, S.H. \& Kalgora, B., 2019. The Selection of Dry Port Location by Analytic Network Process Model: A Case Study of Dosso-Niger. Journal of Transportation Technologies, 09(02), pp.146-155. Available at: http://dx.doi.org/10.4236/jtts.2019.92009.
Awad-Núñez, S. et al., 2016. A Methodology for Measuring Sustainability of Dry Ports Location Based on Bayesian Networks and Multi-criteria Decision Analysis. Transportation Research Procedia, 13, pp.124-133. Available at: http://dx.doi.org/10.1016/j.trpro.2016.05.013.

Bask, A. et al., 2014. Development of seaport-dry port dyads: two cases from Northern Europe. Journal of Transport Geography, 39, pp.85-95. Available at: http://dx.doi.org/10.1016/j.jtrangeo.2014.06.014.

Bentaleb, F. et al., 2016a. Dry port-seaport system development: Application of the product life cycle theory. Journal of Transportation and Logistics, 1(2), pp.115-128. Available at:

http://dx.doi.org/10.22532/jtl.267840.

Bentaleb, F., Mabrouki, C. \& Semma, A., 2016b. Dry Port Location Problem: A Hybrid Multi-Criteria Approach. Journal of ETA Maritime Science, 4(1), pp.73-90. Available at: http://dx.doi.org/10.5505/jems.2016.81300.

Bentaleb, F., Mabrouki, C. \& Semma, A., 2015a. Key Performance Indicators Evaluation and Performance Measurement in Dry Port-Seaport System: A Multi Criteria Approach. Journal of ETA Maritime Science, 3(2), pp.97-116. Available at: http://dx.doi.org/10.5505/jems.2015.88597.

Bentaleb, F., Mabrouki, C. \& Semma, A., 2015b. A Multi-Criteria Approach for Risk Assessment of Dry Port-Seaport System. Supply Chain Forum: An International Journal, 16(4), pp.32-49. Available at:

http://dx.doi.org/10.1080/16258312.2015.11728692.

Bentaleb, F., Mabrouki, C. \& Semma, A., 2015c. Dry Port Development: A Systematic Review. Journal of ETA Maritime Science, 3(2), pp.75-96. Available at: http://dx.doi.org/10.5505/jems.2015.98608.

Van den Berg, R. \& De Langen, P.W., 2014. Towards an "inland terminal centred" value proposition. Maritime Policy \& Management, 42(5), pp.499-515. Available at: http://dx.doi.org/10.1080/03088839.2014.928955.

Cortés, P. et al., 2007. Simulation of freight traffic in the Seville inland port. Simulation Modelling Practice and Theory, 15(3), pp.256-271. Available at:

http://dx.doi.org/10.1016/j.simpat.2006.11.004.

Crainic, T.G. et al., 2015. Modeling dry-port-based freight distribution planning. Transportation Research Part C: Emerging Technologies, 55, pp.518-534. Available at: http://dx.doi.org/10.1016/j.trc.2015.03.026.

Do, N.-H., Nam, K.-C. \& Le, Q.-L.N., 2011. A consideration for developing a dry port system in Indochina area. Maritime Policy \& Management, 38(1), pp.1-9. Available at: http://dx.doi.org/10.1080/03088839.2010.533712.

Gong, Z. \& Liu, N., 2019. Mitigative and adaptive investments for natural disasters and labor strikes in a seaport-dry port inland logistics network. Maritime Policy \& Management, 47(1), pp.92-108. Available at:

http://dx.doi.org/10.1080/03088839.2019.1675195

Hanaoka, S. \& Regmi, M.B., 2011. Promoting intermodal freight transport through the development of dry ports in Asia: An environmental perspective. IATSS Research, 35(1), pp.16-23. Available at:

http://dx.doi.org/10.1016/j.iatssr.2011.06.001.

Haralambides, H. \& Gujar, G., 2011. The Indian dry ports sector, pricing policies and opportunities for public-private partnerships. Research in Transportation Economics, 33(1), pp.51-58. Available at: http://dx.doi.org/10.1016/j.retrec.2011.08.006.

Hayut, Y., 1980. Inland container terminal-function and rationale. Maritime Policy \& Management, 7(4), pp.283-289. Available at: http://dx.doi.org/10.1080/03088838000000042. 
Henttu, V., Lättilä, L., Hilmola, O.-P., 2011. Optimization of Relative Transport Costs of a Hypothetical Dry Port Structure.

Hervás-Peralta, M. et al., 2019. Improving the Performance of Dry and Maritime Ports by Increasing Knowledge about the Most Relevant Functionalities of the Terminal Operating System (TOS). Sustainability, 11(6), p.1648. Available at: http://dx.doi.org/10.3390/su11061648.

Hirst, P., Thompson, G., Bromley, S., 2009. Globalization in Question (3rd edition). Polity, Cambridge, UK / Malden, MA, USA.

Jaržemskis, A. \& Vasiliauskas, A.V., 2007. Research on Dry Port Concept as Intermodal Node. Transport, 22(3), pp.207-213. Available at:

http://dx.doi.org/10.3846/16484142.2007.9638126.

Ka, B., 2011. Application of Fuzzy AHP and ELECTRE to China Dry Port Location Selection. The Asian Journal of Shipping and Logistics, 27(2), pp.331-353. Available at: http://dx.doi.org/10.1016/s2092-5212(11)80015-5.

Komchornrit, K., 2017. The Selection of Dry Port Location by a Hybrid CFA-MACBETHPROMETHEE Method: A Case Study of Southern Thailand. The Asian Journal of Shipping and Logistics, 33(3), pp.141-153. Available at: http://dx.doi.org/10.1016/j.ajsl.2017.09.004

Lättilä, L., Henttu, V. \& Hilmola, O.-P., 2013. Hinterland operations of sea ports do matter: Dry port usage effects on transportation costs and $\mathrm{CO} 2$ emissions. Transportation Research Part E: Logistics and Transportation Review, 55, pp.23-42. Available at:

http://dx.doi.org/10.1016/j.tre.2013.03.007.

Li, J., Jiang, B., 2014. Cooperation Performance Evaluation between Seaport and Dry Port; Case of Qingdao Port and Xi'an Port. International Journal of e-Navigation and Maritime Economy 1,99-109. Available at: https://doi.org/10.1016/j.enavi.2014.12.009.

Li, W., Hilmola, O.-P. \& Panova, Y., 2019. Container Sea Ports and Dry Ports: Future CO2 Emission Reduction Potential in China. Sustainability, 11(6), p.1515. Available at: http://dx.doi.org/10.3390/su11061515.

Mabrouki, C., Bentaleb, F. \& Mousrij, A., 2014. A decision support methodology for risk management within a port terminal. Safety Science, 63, pp.124-132. Available at: http://dx.doi.org/10.1016/j.ssci.2013.09.015.

Ng, A.K.Y., Girish, G., 2009. The spatial characteristics of dry ports in India, in: Transport and Communications Bulletin for Asia and the Pacific. pp. 102-111.

Nguyen, L.C. \& Notteboom, T., 2016. A Multi-Criteria Approach to Dry Port Location in Developing Economies with Application to Vietnam. The Asian Journal of Shipping and Logistics, 32(1), pp.23-32. Available at:

http://dx.doi.org/10.1016/j.ajsl.2016.03.003

Notteboom, T., Rodrigue, J.-P., 2009. Inland terminals within North American and European supply chains, in: Transport and Communications Bulletin for Asia and the Pacific. pp. 1-39.

Rodrigue, J.-P. \& Notteboom, T., 2012. Dry ports in European and North American intermodal rail systems: Two of a kind? Research in Transportation Business \& Management, 5, pp.4-15. Available at: http://dx.doi.org/10.1016/j.rtbm.2012.10.003.

Roso, V., 2007. Evaluation of the dry port concept from an environmental perspective: A note. Transportation Research Part D: Transport and Environment, 12(7), pp.523-527. Available at: http://dx.doi.org/10.1016/j.trd.2007.07.001
Roso, Brnjac \& Abramovic, 2015. Inland Intermodal Terminals Location Criteria Evaluation: The Case of Croatia. Transportation Journal, 54(4), p.496. Available at: http://dx.doi.org/10.5325/transportationj.54.4.0496.

Roso, V. \& Lumsden, K., 2010. A review of dry ports. Maritime Economics \& Logistics, 12(2), pp.196-213. Available at:

http://dx.doi.org/10.1057/mel.2010.5.

Roso, V., Woxenius, J. \& Lumsden, K., 2009. The dry port concept: connecting container seaports with the hinterland. Journal of Transport Geography, 17(5), pp.338-345. Available at:

http://dx.doi.org/10.1016/j.jtrangeo.2008.10.008.

Rožić, T., Rogić, K. \& Bajor, I., 2016. Research Trends of Inland Terminals: A Literature Review. PROMET - Traffic\&Transportation, 28(5), pp.539-548. Available at: http://dx.doi.org/10.7307/ptt.v28i5.2090.

Santarremigia, F.E. et al., 2018. Railway safety by designing the layout of inland terminals with dangerous goods connected with the rail transport system. Safety Science, 110, pp.206-216. Available at: http://dx.doi.org/10.1016/j.ssci.2018.03.001.

Tsao, Y.-C. \& Thanh, V.-V., 2019. A multi-objective mixed robust possibilistic flexible programming approach for sustainable seaport-dry port network design under an uncertain environment. Transportation Research Part E: Logistics and Transportation Review, 124, pp.13-39. Available at: http://dx.doi.org/10.1016/j.tre.2019.02.006

UNCTAD, 2018. Review of Maritime Transport 2018.

UNCTAD, 1991. Handbook on the Management and Operation of Dry Ports.

Wang, Y., 2014. Reaserch on Sustainable Development of Inland Port - Hinterland System Based on Life-Cycle Theory. Advanced Materials Research, 962-965, pp.2485-2488. Available at:

http://dx.doi.org/10.4028/www.scientific.net/amr.962-965.2485.

Wei, J., Sun, A. \& Zhuang, J., 2010. The Selection of Dry Port Location with the Method of Fuzzy-ANP. Advances in Wireless Networks and Information Systems, pp.265-273. Available at:

http://dx.doi.org/10.1007/978-3-642-14350-2_33.

Wiegmans, B., Witte, P. \& Spit, T., 2015. Characteristics of European inland ports: A statistical analysis of inland waterway port development in Dutch municipalities. Transportation Research Part A: Policy and Practice, 78, pp.566-577. Available at: http://dx.doi.org/10.1016/j.tra.2015.07.004.

Wilmsmeier, G., Monios, J. \& Lambert, B., 2011. The directional development of intermodal freight corridors in relation to inland terminals. Journal of Transport Geography, 19(6), pp.1379-1386. Available at: http://dx.doi.org/10.1016/j.jtrangeo.2011.07.010.

Witte, P., Wiegmans, B. \& Ng, A.K.Y., 2019. A critical review on the evolution and development of inland port research. Journal of Transport Geography, 74, pp.53-61. Available at:

http://dx.doi.org/10.1016/j.jtrangeo.2018.11.001.

Woxenius, J., Roso, V., Lumsden, K., 2004. The dry port concept-connecting seaports with their hinterland by rail.

Vernon, R., 1966. International Investment and International Trade in the Product Cycle. The Quarterly Journal of Economics, 80(2), p.190. Available at: http://dx.doi.org/10.2307/1880689. 


\section{SUPPLEMENT}

\begin{tabular}{|c|c|c|}
\hline Theme & Number of articles & Articles \\
\hline Financial impact & 12 & $\begin{array}{l}\text { (Haralambides and Gujar, 2011), (Henttu and Hilmola, 2011), (Henttu et al., 2011), } \\
\text { (Lättilä et al., 2013),(Panova and Hilmola, 2015), (Smid et al., 2016), (Facchini et al., } \\
\text { 2020), (Qiu and Lee, 2019), (Whitman et al., 2019), (Qiu and Xu, 2019), (lannone, } \\
\text { 2012), (Chang et al., 2019a). }\end{array}$ \\
\hline Risk management & 8 & $\begin{array}{l}\text { (Schindlbacher et al., 2011), (Panova and Hilmola, 2015), (Bentaleb et al., 2015c), } \\
\text { (Molero et al., 2017), (Santarremigia et al., 2018), (Ng et al., 2015), (Gong and Liu, } \\
\text { 2020), (Yosef et al., 2019). }\end{array}$ \\
\hline Environmental impact & 17 & $\begin{array}{l}\text { (Roso, 2007), (Roso, 2009), (Hanaoka and Regmi, 2011), (Henttu and Hilmola, 2011), } \\
\text { (Haralambides and Gujar, 2012), (Dooms et al., 2013), (Lättilä et al., 2013), (Wu et al., } \\
\text { 2014), (Muravev and Rakhmangulov, 2016), (Seguí et al., 2016), (Vejvar et al., 2018), } \\
\text { (Tsao and Linh, 2018), (Pham and Lee, 2019), (Chang et al., 2019a), (Li et al., 2019), } \\
\text { (Wei and Sheng, 2017), (Qiu and Lam, 2018). }\end{array}$ \\
\hline
\end{tabular}

Durability/Sustainability 15

(Cullinane and Wilmsmeier, 2011), (Beresford et al., 2012), (Rodrigue and Notteboom, 2012), (Wu et al., 2014), (Wang, 2014), (Awad-Núñez et al., 2015), (Awad-Núñez et al., 2016a), (Awad-Núñez et al., 2016b), (Vejvar et al., 2018), (Muravev et al., 2019), (Ližbetin, 2019), (Tsao and Thanh, 2019), (Wei and Sheng, 2017), (Hui et al., 2019), (Wiercx et al., 2019), .

Location management 32

(Roso, 2008), (Rahimi et al., 2008), (Rosa and Roscelli, 2009), (Ng and Girish, 2009),(Wei et al., 2010), (Chang et al., 2011), (Flämig and Hesse, 2011), (Bentaleb et al., 2016a), (Ka, 2011), (Feng et al., 2013), (Rožić et al., 2014), (Ambrosino and Sciomachen, 2014), (Awad-Núñez et al., 2014), (Chang et al., 2015), (Awad-Núñez et al., 2015), (Roso et al., 2015a), (Awad-Núñez et al., 2016a), (Awad-Núñez et al., 2016b), (Muravev and Rakhmangulov, 2016), (Nguyen and Notteboom, 2016), (Wang et al., 2018), (Komchornrit, 2017), (Monios and Wilmsmeier, 2012a), (Santos and Guedes Soares, 2017), (Raimbault, 2019), (Ližbetin, 2019), (Van Nguyen et al., 2019), (Chang et al., 2019a), (Gonzalez-Aregall and Bergqvist, 2019), (Owusu Kwateng et al., 2017), (Black et al., 2018), (Sun and Wang, 2018), (Abdoulkarim et al., 2019b).

Concept $66 \quad$ (Hayut, 1980), (UNCTAD, 1991), (WALTER and POIST, 2003), (Wood, 2004), (Woxenius et al., 2004), (Walter and Poist, 2004), (Jaržemskis and Vasiliauskas, 2007), (Roso, 2007), (Roso et al., 2009), (Ng and Girish, 2009), (K. Y. A. Ng and Gujar, 2009), (Roso and Lumsden, 2009), (Notteboom and Rodrigue, 2009), (Cronje et al., 2009), (AdolfK. Y. Ng and Gujar, 2009), (Caballini and Gattorna, 2009), (Rodrigue et al., 2010), (Bentaleb et al., 2015a), (Roso and Lumsden, 2010), (Ng and Tongzon, 2010), (Hanaoka and Regmi, 2011), (Monios, 2011), (Dadvar et al., 2011), (Cullinane and Wilmsmeier, 2011), (Do et al., 2011), (Korovyakovsky and Panova, 2011), (Cullinane et al., 2012), (Beresford et al., 2012), (Monios and Wilmsmeier, 2012b), (Veenstra et al., 2012), (Chen and Wang, 2012), (Ng and Cetin, 2012), (Ng et al., 2013), (Lättilä et al., 2013), (Zeng et al., 2013), (Rožić et al., 2014), (Bask et al., 2014), (Witte et al., 2014), (Wang, 2014), (Crainic et al., 2015), (Li et al., 2015), (Panova and Hilmola, 2015), (Wiegmans et al., 2015a), (Jeevan et al., 2015), (Berg and Langen, 2015), (Rožić et al., 2016), (Nguyen and Notteboom, 2016), (Witte et al., 2016), (Wang et al., 2018), (Witte et al., 2017), (Wei et al., 2018), (Nguyen and Notteboom, 2019), (Tsao and Linh, 2018), (González-Sánchez et al., 2015), (Witte et al., 2019), (Caris et al., 2014), (Santos and Guedes Soares, 2017), (Pham and Lee, 2019),(Roso et al., 2019),(Tsao and Thanh, 2019)(Montwiłł, 2019), (Khaslavskaya and Roso, 2019), (Bentaleb et al., 2016b), (Protic et al., 2019), (Zhang et al., 2006), (Wiegmans et al., 2019), (Black et al., 2018), (Qiu and Lam, 2018). 


Performance 66

(Kondratowicz, 1992), (WALTER and POIST, 2003), (Wood, 2004), (Walter and Poist, 2004), (Cortés et al., 2007), (Cronje et al., 2009), (Garnwa et al., 2009), (AdolfK. Y. Ng and Gujar, 2009), (Hanaoka and Regmi, 2011), (Monios, 2011), (Schindlbacher et al., 2011), (Arango et al., 2011), (Garnwa et al., 2009), (Carrese and Tatarelli, 2011), (Van den Berg and De Langen, 2011), (Liedtke and Carrillo Murillo, 2012), (Padilha and Ng, 2012), (Monios and Wilmsmeier, 2012b), (Rodrigue and Notteboom, 2012), (Chen and Wang, 2012), (Ng and Cetin, 2012), (Mundutéguy, 2012), (Dooms et al., 2013), (Monios and Wang, 2013), (Wen and Chen, 2013), (Wang et al., 2014), (Li and Jiang, 2014), (Witte et al., 2014), (Martínez-Pardo and Garcia-Alonso, 2014), (Wilmsmeier et al., 2015), (Qiu et al., 2015), (Clausen and Kaffka, 2016), (Roso et al., 2015b), (Bentaleb et al., 2015b), (Wiegmans et al., 2015b), (Andersson and Roso, 2016), (Li et al., 2017), (Seguí et al., 2016), (Witte et al., 2016), (Witte et al., 2017), (Wei and Sheng, 2018), (Jeevan et al., 2017), (Jeevan et al., 2018), (Lizbetin and Bartuska, 2019), (Wei et al., 2018), (Carboni and Deflorio, 2018), (Kramberger et al., 2018), (Chang et al., 2019b), (Fazi and Roodbergen, 2018), (Tan et al., 2018), (Oláh et al., 2018), (Wan et al., 2018), (Smid et al., 2016), (Tadić et al., 2019), (Lizbetin and Bartuska, 2019), (Jeevan et al., 2019), (Hossain et al., 2019), (Whitman et al., 2019), (lannone, 2012), (Khaslavskaya and Roso, 2019), (Gonzalez-Aregall and Bergqvist, 2019), (Protic et al., 2019), (Abdoulkarim et al., 2019a), (Chen et al., 2017), (Hui et al., 2019), (Chen et al., 2018), (Musso and Sciomachen, 2019).

Optimization 23

(K. Y. A. Ng and Gujar, 2009), (Arango et al., 2011), (Carrese and Tatarelli, 2011), (Henttu et al., 2011), (Chang et al., 2011), (Mundutéguy, 2012), (Lam and Gu, 2013), (Crainic et al., 2015), (Qiu et al., 2015), (Rathnayake et al., 2015), (Andersson and Roso, 2016), (Debrie and Raimbault, 2016), (Jeevan et al., 2017), (Nguyen and Notteboom, 2017), (Fazi and Roodbergen, 2018), (Tsao and Linh, 2018), (Wei and Dong, 2019), (Van Nguyen et al., 2019), (Qiu and Xu, 2019), (Chang et al., 2019a), (Zhang et al., 2006), (Wei and Sheng, 2017), (Ji et al., 2019).

\section{REFERENCES}

Abdoulkarim, H.T., Fatouma, S.H., Hassane, H.T., 2019a. Assessment of Dry Port Efficiency in Africa Using Data Envelopment Analysis. Journal of Transportation Technologies 09, 193. https://doi.org/10.4236/jtts.2019.92012

Abdoulkarim, H.T., Fatouma, S.H., Kalgora, B., 2019b. The Selection of Dry Port Location by Analytic Network Process Model: A Case Study of Dosso-Niger. Journal of Transportation Technologies 09, 146. https://doi.org/10.4236/jtts.2019.92009

Ambrosino, D., Sciomachen, A., 2014. Location of Mid-range Dry Ports in Multimodal Logistic Networks. Procedia - Social and Behavioral Sciences 108, 118-128. https:// doi.org/10.1016/j.sbspro.2013.12.825

Andersson, D., Roso, V., 2016. Developing Dry Ports Through the Use of ValueAdded Services, in: Clausen, U., Friedrich, H., Thaller, C., Geiger, C. (Eds.), Commercial Transport, Lecture Notes in Logistics. Springer International Publishing, Cham, pp. 191-203. https://doi.org/10.1007/978-3-319-21266-1_12

Arango, C., Cortés, P., Muñuzuri, J., Onieva, L., 2011. Berth allocation planning in Seville inland port by simulation and optimisation. Advanced Engineering Informatics, Special Section: Engineering informatics in port operations and logistics 25, 452-461. https://doi.org/10.1016/j.aei.2011.05.001

Awad-Núñez, S., González-Cancelas, N., Camarero-Orive, A., 2014. Application of a Model based on the Use of DELPHI Methodology and Multicriteria Analysis for the Assessment of the Quality of the Spanish Dry Ports Location. Procedia - Social and Behavioral Sciences, XVIII Congreso Panamericano de Ingeniería de Tránsito, Transporte y Logística (PANAM 2014) 162, 42-50. https://doi.org/10.1016/j. sbspro.2014.12.184
Awad-Núñez, S., González-Cancelas, N., Soler-Flores, F., Camarero-Orive, A., 2016a. A Methodology for Measuring Sustainability of Dry Ports Location Based on Bayesian Networks and Multi-criteria Decision Analysis. Transportation Research Procedia, Towards future innovative transport: visions, trends and methods 43rd European Transport Conference Selected Proceedings 13, 124-133. https://doi.org/10.1016/j. trpro.2016.05.013

Awad-Núñez, S., González-Cancelas, N., Soler-Flores, F., Camarero-Orive, A., 2015. How should the sustainability of the location of dry ports be measured? A proposed methodology using Bayesian networks and multi-criteria decision analysis. Transport 30, 312-319. https://doi.org/10.3846/16484142.2015.1081618

Awad-Núñez, S., Soler-Flores, F., González-Cancelas, N., Camarero-Orive, A., 2016b. How should the Sustainability of the Location of Dry Ports be Measured? Transportation Research Procedia, Transport Research Arena TRA2016 14, 936-944. https://doi.org/10.1016/j.trpro.2016.05.073

Bask, A., Roso, V., Andersson, D., Hämäläinen, E., 2014. Development of seaport-dry port dyads: two cases from Northern Europe. Journal of Transport Geography 39, 85-95. https://doi.org/10.1016/j.jtrangeo.2014.06.014

Bentaleb, F., Mabrouki, C., Semma, A., 2015c. A Multi-Criteria Approach for Risk Assessment of Dry Port-Seaport System. Supply Chain Forum: An International Journal 16, 32-49. https://doi.org/10.1080/16258312.2015.11728692

Bentaleb, F. Mabrouki, C. Semma A., 2015a. Dry Port Development: A Systematic Review, Journal of ETA Maritime Science, Volume 3, Issue 1, Pages 75 - 96.

Bentaleb, F. Mabrouki, C. Semma A., 2015b. Key Performance Indicators Evaluation and Performance Measurement in Dry Port-Seaport System: A Multi Criteria 
Approach, Journal of ETA Maritime Science, Volume 3, Issue 1, Pages 97 -116.

Bentaleb, F. Mabrouki, C. Semma A., 2016a. Dry Port Location Problem: A Hybrid Multi-Criteria Approach, Journal of ETA Maritime Science, Volume 4, Issue 1, Pages $73-90$.

Beresford, A., Pettit, S., Xu, Q., Williams, S., 2012. A study of dry port development in China. Marit Econ Logist 14, 73-98. https://doi.org/10.1057/mel.2011.17

Berg, R.V. den, Langen, P.W.D., 2015. Towards an 'inland terminal centred' value proposition. Maritime Policy \& Management 42, 499-515. https://doi.org/10.1080 /03088839.2014.928955

Black, J., Roso, V., Marušić, E., Brnjac, N., 2018. Issues in Dry Port Location and Implementation in Metropolitan Areas: The Case of Sydney, Australia. Transactions on Maritime Science 07, 41-50. https://doi.org/10.7225/toms.v07.n01.004

Caballini, C., Gattorna, E., 2009. THE EXPANSION OF THE PORT OF GENOA: THE RIVALTA SCRIVIA DRY PORT 14.

Carboni, A., Deflorio, F., 2018. Performance indicators and automatic identification systems in inland freight terminals for intermodal transport. IET Intelligent Transport Systems 12, 309-318. https://doi.org/10.1049/iet-its.2017.0349

Caris, A., Limbourg, S., Macharis, C., van Lier, T., Cools, M., 2014. Integration of inland waterway transport in the intermodal supply chain: a taxonomy of research challenges. Journal of Transport Geography 41, 126-136. https://doi.org/10.1016/j. jtrangeo.2014.08.022

Carrese, S., Tatarelli, L., 2011. Optimizing the stacking of the Intermodal Transport Units in an inland terminal: an heuristic procedure. Procedia - Social and Behavioral Sciences, The State of the Art in the European Quantitative Oriented Transportation and Logistics Research - 14th Euro Working Group on Transportation \& 26th Mini Euro Conference \& 1st European Scientific Conference on Air Transport 20, 9941003. https://doi.org/10.1016/j.sbspro.2011.08.108

Chang, Z., Lu, J., Qi, Z., 2011. Location Analysis for Dry Ports Based on FCM [WWW Document]. Applied Mechanics and Materials. https://doi.org/10.4028/www. scientific.net/AMM.97-98.1022

Chang, Z., Notteboom, T., Lu, J., 2015. A two-phase model for dry port location with an application to the port of Dalian in China. Transportation Planning and Technology 38, 442-464. https://doi.org/10.1080/03081060.2015.1026103

Chang, Z., Weng, J., Qi, Z., Yang, D., 2019a. Assess economic and environmental trade-off for inland port location. International Journal of Shipping and Transport Logistics 11, 243-261. https://doi.org/10.1504/IJSTL.2019.099277

Chang, Z., Yang, D., Wan, Y., Han, T., 2019b. Analysis on the features of Chinese dry ports: Ownership, customs service, rail service and regional competition. Transport Policy 82, 107-116. https://doi.org/10.1016/j.tranpol.2018.06.008

Chen, H., Cullinane, K., Liu, N., 2017. Developing a model for measuring the resilience of a port-hinterland container transportation network. Transportation Research Part E: Logistics and Transportation Review 97, 282-301. https://doi.org/10.1016/j. tre.2016.10.008

Chen, J., Fei, Y., Zhang, F., Jing, C., 2018. Evaluating Correlations between a Seaport and Its Dry Ports: Case Study of Xiamen Port in China [WWW Document]. Discrete Dynamics in Nature and Society. https://doi.org/10.1155/2018/6831302

Chen, J.H., Wang, Y., 2012. SWOT-PEST Analysis of China's Dry Port [WWW Document]. Advanced Materials Research. https://doi.org/10.4028/www.scientific. net/AMR.479-481.1004

Clausen, U., Kaffka, J., 2016. Development of priority rules for handlings in inland port container terminals with simulation. Journal of Simulation 10, 95-102. https:// doi.org/10.1057/jos.2015.11
Cortés, P., Muñuzuri, J., Nicolás Ibáñez, J., Guadix, J., 2007. Simulation of freight traffic in the Seville inland port. Simulation Modelling Practice and Theory 15, 256-271. https://doi.org/10.1016/j.simpat.2006.11.004

Crainic, T.G., Dell'Olmo, P., Ricciardi, N., Sgalambro, A., 2015. Modeling dry-portbased freight distribution planning. Transportation Research Part C: Emerging Technologies, Engineering and Applied Sciences Optimization (OPT-i) - Professor Matthew G. Karlaftis Memorial Issue 55, 518-534. https://doi.org/10.1016/j. trc.2015.03.026

Cronje, E., Matthee, M., Krugell, W., 2009. THE ROLE OF DRY PORTS IN SOUTH AFRICA 9.

Cullinane, K., Bergqvist, R., Wilmsmeier, G., 2012. The dry port concept - Theory and practice. Marit Econ Logist 14, 1-13. https://doi.org/10.1057/mel.2011.14

Cullinane, K., Wilmsmeier, G., 2011. The Contribution of the Dry Port Concept to the Extension of Port Life Cycles, in: Böse, J.W. (Ed.), Handbook of Terminal Planning, Operations Research/Computer Science Interfaces Series. Springer, New York, NY, pp. 359-379. https://doi.org/10.1007/978-1-4419-8408-1_18

Dadvar, E., Ganji, S.R.S., Tanzifi, M., 2011. Feasibility of establishment of "Dry Ports" in the developing countries-the case of Iran. J Transp Secur 4, 19-33. https://doi. org/10.1007/s12198-010-0056-x

Debrie, J., Raimbault, N., 2016. The port-city relationships in two European inland ports: A geographical perspective on urban governance. Cities 50, 180-187. https:// doi.org/10.1016/j.cities.2015.10.004

Do, N.-H., Nam, K.-C., Le, Q.-L.N., 2011. A consideration for developing a dry port system in Indochina area. Maritime Policy \& Management 38, 1-9. https://doi.org/1 0.1080/03088839.2010.533712

Dooms, M., Haezendonck, E., Valaert, T., 2013. Dynamic green portfolio analysis for inland ports: An empirical analysis on Western Europe. Research in Transportation Business \& Management, Port Performance and Strategy 8, 171-185. https://doi. org/10.1016/j.rtbm.2013.07.006

Facchini, F., Digiesi, S., Mossa, G., 2020. Optimal dry port configuration for container terminals: A non-linear model for sustainable decision making. International Journal of Production Economics 219, 164-178. https://doi.org/10.1016/j.ijpe.2019.06.004

Fazi, S., Roodbergen, K.J., 2018. Effects of demurrage and detention regimes on dryport-based inland container transport. Transportation Research Part C: Emerging Technologies 89, 1-18. https://doi.org/10.1016/j.trc.2018.01.012

Feng, X., Zhang, Y., Li, Y., Wang, W., 2013. A Location-Allocation Model for SeaportDry Port System Optimization [WWW Document]. Discrete Dynamics in Nature and Society. https://doi.org/10.1155/2013/309585

Flämig, H., Hesse, M., 2011. Placing dryports. Port regionalization as a planning challenge - The case of Hamburg, Germany, and the Süderelbe. Research in Transportation Economics, Intermodal Strategies for Integrating Ports and Hinterlands 33, 42-50. https://doi.org/10.1016/j.retrec.2011.08.005

Garnwa, P., Beresford, A.K.C., Pettit, S., 2009. DRY PORTS: A COMPARATIVE STUDY OF THE UNITED KINGDOM AND NIGERIA, in: Transport and Communications Bulletin for Asia and the Pacific.

Gong, Z., Liu, N., 2020. Mitigative and adaptive investments for natural disasters and labor strikes in a seaport-dry port inland logistics network. Maritime Policy \& Management 47, 92-108. https://doi.org/10.1080/03088839.2019.1675195

Gonzalez-Aregall, M., Bergqvist, R., 2019. The role of dry ports in solving seaport disruptions: A Swedish case study. Journal of Transport Geography 80, 102499. https://doi.org/10.1016/j.jtrangeo.2019.102499 
González-Sánchez, G., Olmo-Sánchez, M.I., Maeso-González, E., 2015. Effects of the Implementation of Antequera Dry Port in Export and Import Flows, in: Cortés, P., Maeso-González, E., Escudero-Santana, A. (Eds.), Enhancing Synergies in a Collaborative Environment, Lecture Notes in Management and Industrial Engineering. Springer International Publishing, Cham, pp. 147-154. https://doi. org/10.1007/978-3-319-14078-0_17

Hanaoka, S., Regmi, M.B., 2011. Promoting intermodal freight transport through the development of dry ports in Asia: An environmental perspective. IATSS Research 35, 16-23. https://doi.org/10.1016/j.iatssr.2011.06.001

Haralambides, H., Gujar, G., 2012. On balancing supply chain efficiency and environmental impacts: An eco-DEA model applied to the dry port sector of India. Marit Econ Logist 14, 122-137. https://doi.org/10.1057/mel.2011.19

Haralambides, H., Gujar, G., 2011. The Indian dry ports sector, pricing policies and opportunities for public-private partnerships. Research in Transportation Economics, Intermodal Strategies for Integrating Ports and Hinterlands 33, 51-58. https://doi.org/10.1016/j.retrec.2011.08.006

Hayut, Y., 1980. Inland container terminal-function and rationale. Maritime Policy \& Management 7, 283-289. https://doi.org/10.1080/03088838000000042

Henttu, V., Hilmola, O.-P., 2011. Financial and environmental impacts of hypothetical Finnish dry port structure. Research in Transportation Economics, Intermodal Strategies for Integrating Ports and Hinterlands 33, 35-41. https://doi.org/10.1016/j. retrec.2011.08.004

Henttu, V., Lättilä, L., Hilmola, O.-P., 2011. OPTIMIZATION OF RELATIVE TRANSPORT COSTS OF A HYPOTHETICAL DRY PORT STRUCTURE.

Hossain, N.U.I., Nur, F., Jaradat, R., Hosseini, S., Marufuzzaman, M., Puryear, S.M., Buchanan, R.K., 2019. Metrics for Assessing Overall Performance of Inland Waterway Ports: A Bayesian Network Based Approach [WWW Document]. Complexity. https:// doi.org/10.1155/2019/3518705

Hui, F.K.P., Aye, L., Duffield, C.F., 2019. Engaging Employees with Good Sustainability: Key Performance Indicators for Dry Ports. Sustainability 11, 2967. https://doi. org/10.3390/su11102967

lannone, F., 2012. The private and social cost efficiency of port hinterland container distribution through a regional logistics system. Transportation Research Part A: Policy and Practice 46, 1424-1448. https://doi.org/10.1016/j.tra.2012.05.019

Jaržemskis, A., Vasiliauskas, A.V., 2007. Research on dry port concept as intermodal node. Transport 22, 207-213. https://doi.org/10.1080/16484142.2007.9638126

Jeevan, J., Bandara, Y.M., Mohd Salleh, N.H., Ngah, A.H., Hanafiah, R., 2019. A Procedure of Implementing Exploratry Mixed Method Research in Dry Ports Management. Transactions on Maritime Science 08, 157-170. https://doi.org/10.7225/toms.v08. n02.001

Jeevan, J., Chen, S., Lee, E., 2015. The Challenges of Malaysian Dry Ports Development. The Asian Journal of Shipping and Logistics 31, 109-134. https://doi.org/10.1016/j. ajsl.2015.03.005

Jeevan, J., Chen, S.-L., Cahoon, S., 2018. Determining the influential factors of dry port operations: worldwide experiences and empirical evidence from Malaysia. Marit Econ Logist 20, 476-494. https://doi.org/10.1057/s41278-017-0063-y

Jeevan, J., Salleh, NHM., Loke, K.B., Saharuddin, A.H., 2017. Preparation of dry ports for a competitive environment in the container seaport system: A process benchmarking approach. International Journal of e-Navigation and Maritime Economy 7, 19-33. https://doi.org/10.1016/j.enavi.2017.06.003

Ji, B., Yuan, X., Yuan, Y., Lei, X., Fernando, T., lu, H.H.C., 2019. Exact and heuristic methods for optimizing lock-quay system in inland waterway. European Journal of
Operational Research 277, 740-755. https://doi.org/10.1016/j.ejor.2019.03.010

Ka, B., 2011. Application of Fuzzy AHP and ELECTRE to China Dry Port Location Selection. The Asian Journal of Shipping and Logistics 27, 331-353. https://doi. org/10.1016/S2092-5212(11)80015-5

Khaslavskaya, A., Roso, V., 2019. Outcome-Driven Supply Chain Perspective on Dry Ports. Sustainability 11, 1492. https://doi.org/10.3390/su11051492

Komchornrit, K., 2017. The Selection of Dry Port Location by a Hybrid CFA-MACBETHPROMETHEE Method: A Case Study of Southern Thailand. The Asian Journal of Shipping and Logistics 33, 141-153. https://doi.org/10.1016/j.ajsl.2017.09.004

Kondratowicz, L.J., 1992. Methodological solutions for increased efficiency of modelling and simulation of seaports and inland freight terminals. Maritime Policy \& Management 19, 157-164. https://doi.org/10.1080/03088839200000022

Korovyakovsky, E., Panova, Y., 2011. Dynamics of Russian dry ports. Research in Transportation Economics, Intermodal Strategies for Integrating Ports and Hinterlands 33, 25-34. https://doi.org/10.1016/j.retrec.2011.08.008

Kramberger, T., Monios, J., Strubelj, G., Rupnik, B., 2018. Using dry ports for port co-opetition: the case of Adriatic ports. IJSTL 10, 18. https://doi.org/10.1504/ IJSTL.2018.088319

Lam, J.S.L., Gu, Y., 2013. Port hinterland intermodal container flow optimisation with green concerns : a literature review and research agenda. http://dx.doi.org/10.1504/ IJSTL.2013.054190

Lättilä, L., Henttu, V., Hilmola, O.-P., 2013. Hinterland operations of sea ports do matter: Dry port usage effects on transportation costs and CO2 emissions. Transportation Research Part E: Logistics and Transportation Review, Green Shipping Management 55, 23-42. https://doi.org/10.1016/j.tre.2013.03.007

Li, J., Jiang, B., 2014. Cooperation Performance Evaluation between Seaport and Dry Port; Case of Qingdao Port and Xi'an Port. International Journal of e-Navigation and Maritime Economy 1,99-109. https://doi.org/10.1016/j.enavi.2014.12.009

Li, J.Y., Notteboom, T.E., Wang, J.J., 2017. An institutional analysis of the evolution of inland waterway transport and inland ports on the Pearl River. GeoJournal 82, 867-886. https://doi.org/10.1007/s10708-016-9696-0

Li, W., Hilmola, O.-P., Panova, Y., 2019. Container Sea Ports and Dry Ports: Future CO2 Emission Reduction Potential in China. Sustainability 11, 1515. https://doi. org/10.3390/su11061515

Li, Y., Dong, Q., Sun, S., 2015. Dry Port Development in China: Current Status and Future Strategic Directions. coas 73, 641-646. https://doi.org/10.2112/SI73-111.1

Liedtke, G., Carrillo Murillo, D.G., 2012. Assessment of policy strategies to develop intermodal services: The case of inland terminals in Germany. Transport Policy 24, 168-178. https://doi.org/10.1016/j.tranpol.2012.06.002

Ližbetin, J., 2019. Methodology for Determining the Location of Intermodal Transport Terminals for the Development of Sustainable Transport Systems: A Case Study from Slovakia. Sustainability 11, 1230. https://doi.org/10.3390/su11051230

Lizbetin, J., Bartuska, L., 2019. Significance of Proper Selection of Handling Equipment in Inland Intermodal Transport Terminals. Periodica Polytechnica Transportation Engineering 47, 136-139. https://doi.org/10.3311/PPtr.11169

Martínez-Pardo, A., Garcia-Alonso, L., 2014. Analysis of the Inland Port Regionalization Process in Spain. Procedia - Social and Behavioral Sciences, XVIII Congreso Panamericano de Ingeniería de Tránsito, Transporte y Logística (PANAM 2014) 162, 228-236. https://doi.org/10.1016/j.sbspro.2014.12.203

Molero, G.D., Santarremigia, F.E., Aragonés-Beltrán, P., Pastor-Ferrando, J.-P., 2017. Total safety by design: Increased safety and operability of supply chain of 
inland terminals for containers with dangerous goods. Safety Science, SAFETY: Methods and applications for Total Safety Management 100, 168-182. https://doi. org/10.1016/j.ssci.2016.10.007

Monios, J., 2011. The role of inland terminal development in the hinterland access strategies of Spanish ports. Research in Transportation Economics, Intermodal Strategies for Integrating Ports and Hinterlands 33, 59-66. https://doi.org/10.1016/j. retrec.2011.08.007

Monios, J., Wang, Y., 2013. Spatial and institutional characteristics of inland port development in China. GeoJournal 78, 897-913. https://doi.org/10.1007/s10708013-9473-2

Monios, J., Wilmsmeier, G., 2012a. Giving a direction to port regionalisation. Transportation Research Part A: Policy and Practice 46, 1551-1561. https://doi. org/10.1016/j.tra.2012.07.008

Monios, J., Wilmsmeier, G., 2012b. Port-centric logistics, dry ports and offshore logistics hubs: strategies to overcome double peripherality? Maritime Policy \& Management 39, 207-226. https://doi.org/10.1080/03088839.2011.650720

Montwiłt, A., 2019. Inland ports in the urban logistics system. Case studies. Transportation Research Procedia 333-340.

Mundutéguy, C., 2012. Exploring the Nature and Consequences of a Fragmented Activity: The Example of Foremen Managing Operations in an Inland Port. Work 41, 6039-6046. https://doi.org/10.3233/WOR-2012-1057-6039

Muravev, D., Rakhmangulov, A., 2016. Environmental Factors' Consideration at Industrial Transportation Organization in the «Seaport - Dry port» System. Open Engineering 6. https://doi.org/10.1515/eng-2016-0070

Muravev, D., Rakhmangulov, A., Hu, H., Zhou, H., 2019. The Introduction to System Dynamics Approach to Operational Efficiency and Sustainability of Dry Port's Main Parameters. Sustainability 11, 2413. https://doi.org/10.3390/su11082413

Musso, E., Sciomachen, A., 2019. Impact of megaships on the performance of port container terminals. Marit Econ Logist. https://doi.org/10.1057/s41278-019-00120-y

Ng, AdolfK.Y., Gujar, G.C., 2009. Government policies, efficiency and competitiveness: The case of dry ports in India. Transport Policy, SI: TBGS 16, 232-239. https://doi. org/10.1016/j.tranpol.2009.08.001

Ng, A.K.Y., Cetin, I.B., 2012. Locational Characteristics of Dry Ports in Developing Economies: Some Lessons from Northern India. Regional Studies 46, 757-773. https://doi.org/10.1080/00343404.2010.532117

Ng, A.K.Y., Girish, G., 2009. The spatial characteristics of dry ports in India, in: Transport and Communications Bulletin for Asia and the Pacific. pp. 102-111.

Ng, A.K.Y., Padilha, F., Pallis, A.A., 2013. Institutions, bureaucratic and logistical roles of dry ports: the Brazilian experiences. Journal of Transport Geography, Institutions and the Transformation of Transport Nodes 27, 46-55. https://doi.org/10.1016/j. jtrangeo.2012.05.003

Ng, A.K.Y., Tongzon, J.L., 2010. The Transportation Sector of India's Economy: Dry Ports as Catalysts for Regional Development. Eurasian Geography and Economics 51, 669-682. https://doi.org/10.2747/1539-7216.51.5.669

Ng, A.K.Y., Velasco-Acosta, A.E., Wang, T., 2015. Institutions and the governance of transport infrastructure projects: Some insight from the planning and construction of the CentrePort Canada Way. Research in Transportation Business \& Management, Operational constraints on effective governance of intermodal transport 14, 25-33. https://doi.org/10.1016/j.rtbm.2014.10.012

Ng, K.Y.A., Gujar, G.C., 2009. The spatial characteristics of inland transport hubs: evidences from Southern India. Journal of Transport Geography 17, 346-356. https://doi.org/10.1016/j.jtrangeo.2008.07.010
Nguyen, L.C., Notteboom, T., 2019. The relations between dry port characteristics and regional port-hinterland settings: findings for a global sample of dry ports. Maritime Policy \& Management 46, 24-42. https://doi.org/10.1080/03088839.201 8.1448478

Nguyen, L.C., Notteboom, T., 2017. Public-private partnership model selection for dry port development: an application to Vietnam 22.

Nguyen, L.C., Notteboom, T., 2016. A Multi-Criteria Approach to Dry Port Location in Developing Economies with Application to Vietnam. The Asian Journal of Shipping and Logistics 32, 23-32. https://doi.org/10.1016/j.ajsl.2016.03.003

Notteboom, T., Rodrigue, J.-P., 2009. Inland terminals within North American and European supply chains, in: Transport and Communications Bulletin for Asia and the Pacific. pp. 1-39.

Oláh, J., Nestler, S., Nobel, T., Popp, J., 2018. Ranking of Dry Ports in Europe Benchmarking. Periodica Polytechnica Transportation Engineering 46, 95-100. https://doi.org/10.3311/PPtr.11414

Owusu Kwateng, K., Donkoh, A., Muntaka, A.S., 2017. Evaluation of dry port implementation in Ghana. Maritime Business Review 2, 261-278. https://doi. org/10.1108/MABR-01-2017-0005

Padilha, F., Ng, A.K.Y., 2012. The spatial evolution of dry ports in developing economies: The Brazilian experience. Marit Econ Logist 14, 99-121. https://doi. org/10.1057/mel.2011.18

Panova, Y., Hilmola, O.-P., 2015. Justification and evaluation of dry port investments in Russia. Research in Transportation Economics, Austerity and Sustainable Transportation 51, 61-70. https://doi.org/10.1016/j.retrec.2015.07.008

Pham, H.T., Lee, H., 2019. Developing a Green Route Model for Dry Port Selection in Vietnam. The Asian Journal of Shipping and Logistics 35, 96-107. https://doi. org/10.1016/j.ajsl.2019.06.002

Protic, S.M., Fikar, C., Voegl, J., Gronalt, M., 2019. Analysing the impact of value added services at intermodal inland terminals. International Journal of Logistics Research and Applications 0, 1-19. https://doi.org/10.1080/13675567.2019.1657386

Qiu, X., Lam, J.S.L., 2018. The Value of Sharing Inland Transportation Services in a Dry Port System. Transportation Science 52, 835-849. https://doi.org/10.1287/ trsc.2017.0755

Qiu, X., Lam, J.S.L., Huang, G.Q., 2015. A bilevel storage pricing model for outbound containers in a dry port system. Transportation Research Part E: Logistics and Transportation Review 73, 65-83. https://doi.org/10.1016/j.tre.2014.10.009

Qiu, X., Lee, C.-Y., 2019. Quantity discount pricing for rail transport in a dry port system. Transportation Research Part E: Logistics and Transportation Review 122 563-580. https://doi.org/10.1016/j.tre.2019.01.004

Qiu, X., Xu, G., 2019. Optimizing Rail Transport Service in a Dry Port System. IEEE Transactions on Engineering Management 1-15. https://doi.org/10.1109/ TEM.2019.2951915

Rahimi, M., Asef-Vaziri, A., Harrison, R., 2008. An Inland Port Location-Allocation Model for a Regional Intermodal Goods Movement System. Marit Econ Logist 10, 362-379. https://doi.org/10.1057/mel.2008.17

Raimbault, N., 2019. From regional planning to port regionalization and urban logistics. The inland port and the governance of logistics development in the Paris region. Journal of Transport Geography 78, 205-213. https://doi.org/10.1016/j. jtrangeo.2019.06.005

Rathnayake, J., Jing, L., Erandi, D., 2015. Truck turnaround time problem at the port of Colombo and a solution through inland ports. International Journal of Logistics Systems and Management 21,413-441. https://doi.org/10.1504/IJLSM.2015.070208 
Rodrigue, J.-P., Debrie, J., Fremont, A., Gouvernal, E., 2010. Functions and actors of inland ports: European and North American dynamics. Journal of Transport Geography, Special Issue on Comparative North American and European gateway logistics 18, 519-529. https://doi.org/10.1016/j.jtrangeo.2010.03.008

Rodrigue, J.-P., Notteboom, T., 2012. Dry ports in European and North American intermodal rail systems: Two of a kind? Research in Transportation Business \& Management, Intermodal Freight Transport and Logistics 5, 4-15. https://doi. org/10.1016/j.rtbm.2012.10.003

Rosa, A., Roscelli, R., 2009. Innovative ideas and design of an integrated dry port and seaport system, in: Transport and Communications Bulletin for Asia and the Pacific.

Roso, V., 2009. The emergence and significance of dry ports: the case of the Port of Goteborg. World Review of Intermodal Transportation Research 2, 296-310. https:// doi.org/10.1504/WRITR.2009.026209

Roso, V., 2008. Factors influencing implementation of a dry port. International Journal of Physical Distribution \& Logistics Management 38, 782-798. https://doi. org/10.1108/09600030810926493

Roso, V., 2007. Evaluation of the dry port concept from an environmental perspective: A note. Transportation Research Part D: Transport and Environment 12, 523-527. https://doi.org/10.1016/j.trd.2007.07.001

Roso, V., Brnjac, N., Abramovic, B., 2015a. Inland Intermodal Terminals Location Criteria Evaluation: The Case of Croatia. Transportation Journal 54, 496-515. https:// doi.org/10.5325/transportationj.54.4.0496

Roso, V., Lumsden, K., 2010. A review of dry ports. Marit Econ Logist 12, 196-213. https://doi.org/10.1057/mel.2010.5

Roso, V., Lumsden, K., 2009. THE DRY PORT CONCEPT: MOVING SEAPORT ACTIVITIES INLAND? 15.

Roso, V., Russell, D., Rhoades, D., 2019. Diffusion of Innovation Assessment of Adoption of the Dry Port Concept. Transactions on Maritime Science 08, 26-36. https://doi.org/10.7225/toms.v08.n01.003

Roso, V., Russell, D., Ruamsook, K., Stefansson, G., 2015b. Seaport-inland port dyad dynamics: an investigation of service provisions and intermodal transportation linkages. World Review of Intermodal Transportation Research 5, 263-280. https:// doi.org/10.1504/WRITR.2015.069242

Roso, V., Woxenius, J., Lumsden, K., 2009. The dry port concept: connecting container seaports with the hinterland. Journal of Transport Geography 17, 338-345. https:// doi.org/10.1016/j.jtrangeo.2008.10.008

Rožić, T., Petrović, M., Ogrizović, D., 2014. CONTAINER TRANSPORT FLOWS AS A PREREQUISITE FOR DETERMINATION OF INLAND TERMINAL LOCATION. Pomorstvo 28, 3-9.

Rožić, T., Rogić, K., Bajor, I., 2016. Research Trends of Inland Terminals: A Literature Review. Promet - Traffic\&Transportation 28, 539-548. https://doi.org/10.7307/ptt. v28i5.2090

Santarremigia, F.E., Molero, G.D., Poveda-Reyes, S., Aguilar-Herrando, J., 2018. Railway safety by designing the layout of inland terminals with dangerous goods connected with the rail transport system. Safety Science, Railway safety $110,206-$ 216. https://doi.org/10.1016/j.ssci.2018.03.001

Santos, T.A., Guedes Soares, C., 2017. Development dynamics of the Portuguese range as a multi-port gateway system. Journal of Transport Geography 60, 178-188. https://doi.org/10.1016/j.jtrangeo.2017.03.003

Schindlbacher, E., Gronalt, M., Hauslmayer, H., 2011. Multi-agent simulation for analysing the robustness of inland container terminal networks. International
Journal of Simulation and Process Modelling 6, 317-328. https://doi.org/10.1504/ IJSPM.2011.048012

Seguí, X., Puig, M., Quintieri, E., Wooldridge, C., Darbra, R.M., 2016. New environmental performance baseline for inland ports: A benchmark for the European inland port sector. Environmental Science \& Policy 58, 29-40. https://doi.org/10.1016/j. envsci.2015.12.014

Smid, M., Dekker, S., Wiegmans, B., 2016. Modeling the cost sensitivity of intermodal inland waterway terminals: A scenario based approach. Transportation Research Part A: Policy and Practice 85, 112-122. https://doi.org/10.1016/j.tra.2016.01.006

Sun, J., Wang, H., 2018. The Location Analysis on Dry Port of the Inland in Jinan City. E3S Web Conf. 38, 01035. https://doi.org/10.1051/e3sconf/20183801035

Tadić, S., Krstić, M., Brnjac, N., 2019. Selection of efficient types of inland intermodal terminals. Journal of Transport Geography 78, 170-180. https://doi.org/10.1016/j. jtrangeo.2019.06.004

Tan, Z., Meng, Q., Wang, F., Kuang, H., 2018. Strategic integration of the inland port and shipping service for the ocean carrier. Transportation Research Part E: Logistics and Transportation Review 110, 90-109. https://doi.org/10.1016/j.tre.2017.12.010

Tsao, Y.-C., Linh, V.T., 2018. Seaport- dry port network design considering multimodal transport and carbon emissions. Journal of Cleaner Production 199, 481-492. https://doi.org/10.1016/j.jclepro.2018.07.137

Tsao, Y.-C., Thanh, V.-V., 2019. A multi-objective mixed robust possibilistic flexible programming approach for sustainable seaport-dry port network design under an uncertain environment. Transportation Research Part E: Logistics and Transportation Review 124,13-39. https://doi.org/10.1016/j.tre.2019.02.006

UNCTAD, 1991. Handbook on the Management and Operation of Dry Ports.

Van den Berg, R., De Langen, P.W., 2011. Hinterland strategies of port authorities: A case study of the port of Barcelona. Research in Transportation Economics, Intermodal Strategies for Integrating Ports and Hinterlands 33, 6-14. https://doi. org/10.1016/j.retrec.2011.08.002

Van Nguyen, T., Zhang, J., Zhou, L., Meng, M., He, Y., 2019. A data-driven optimization of large-scale dry port location using the hybrid approach of data mining and complex network theory. Transportation Research Part E: Logistics and Transportation Review 101816. https://doi.org/10.1016/j.tre.2019.11.010

Veenstra, A., Zuidwijk, R., van Asperen, E., 2012. The extended gate concept for container terminals: Expanding the notion of dry ports. Marit Econ Logist 14, 14-32. https://doi.org/10.1057/mel.2011.15

Vejvar, M., Lai, K., Lo, C.K.Y., Fürst, E.W.M., 2018. Strategic responses to institutional forces pressuring sustainability practice adoption: Case-based evidence from inland port operations. Transportation Research Part D: Transport and Environment 61, 274-288. https://doi.org/10.1016/j.trd.2017.08.014

Walter, C.K., Poist, R.F., 2004. North American inland port development: international vs domestic shipper preferences. International Journal of Physical Distribution \& Logistics Management 34, 579-597. https://doi.org/10.1108/09600030410552267

WALTER, C.K., POIST, R.F., 2003. Desired Attributes of an Inland Port: Shipper vs. Carrier Perspectives. Transportation Journal 42, 42-55.

Wan, C., Zhang, D., Fang, H., 2018. Incorporating AHP and Evidential Reasoning for Quantitative Evaluation of Inland Port Performance, in: Lee, P.T.-W., Yang, Z. (Eds.), Multi-Criteria Decision Making in Maritime Studies and Logistics: Applications and Cases, International Series in Operations Research \& Management Science. Springer International Publishing, Cham, pp. 151-173. https://doi.org/10.1007/978-3-31962338-2 7 
Wang, A., Lai, S., Mohmand, Y.T., 2014. Evolution of inland container distribution among the cluster of ports in the Greater Pearl River Delta. Transportation Letters 6, 206-218. https://doi.org/10.1179/1942787514Y.0000000029

Wang, C., Chen, Q., Huang, R., 2018. Locating dry ports on a network: a case study on Tianjin Port. Maritime Policy \& Management 45, 71-88. https://doi.org/10.1080/ 03088839.2017.1330558

Wang, Y., 2014. Reaserch on Sustainable Development of Inland Port - Hinterland System Based on Life-Cycle Theory. Advanced Materials Research 2485-2488. https://doi.org/10.4028/www.scientific.net/AMR.962-965.2485

Wei, H., Dong, M., 2019. Import-export freight organization and optimization in the dry-port-based cross-border logistics network under the Belt and Road Initiative. Computers \& Industrial Engineering 130, 472-484. https://doi.org/10.1016/j. cie.2019.03.007

Wei, H., Sheng, Z., 2018. Logistics connectivity considering import and export for Chinese inland regions in the $21 \mathrm{st}$-Century Maritime Silk Road by dry ports. Maritime Policy \& Management 45, 53-70. https://doi.org/10.1080/03088839.2017.1403052

Wei, H., Sheng, Z., 2017. Dry Ports-Seaports Sustainable Logistics Network Optimization: Considering the Environment Constraints and the Concession Cooperation Relationships. Polish Maritime Research 24, 143-151. https://doi. org/10.1515/pomr-2017-0117

Wei, H., Sheng, Z., Lee, P.T.-W., 2018. The role of dry port in hub-and-spoke network under Belt and Road Initiative. Maritime Policy \& Management 45, 370-387. https:// doi.org/10.1080/03088839.2017.1396505

Wei, J., Sun, A., Zhuang, J., 2010. The Selection of Dry Port Location with the Method of Fuzzy-ANP, in: Luo, Q. (Ed.), Advances in Wireless Networks and Information Systems, Lecture Notes in Electrical Engineering. Springer, Berlin, Heidelberg, pp. 265-273. https://doi.org/10.1007/978-3-642-14350-2_33

Wen, X., Chen, N., 2013. Studies on Evaluation of Modernization of the Inland Port and Shipping Management based on DPSIR Model and Gray Correlation Evaluation Model. Procedia - Social and Behavioral Sciences, Intelligent and Integrated Sustainable Multimodal Transportation Systems Proceedings from the 13th COTA International Conference of Transportation Professionals (CICTP2013) 96, 17921800. https://doi.org/10.1016/j.sbspro.2013.08.204

Whitman, M., Baroud, H., Barker, K., 2019. Multicriteria risk analysis of commodityspecific dock investments at an inland waterway port. The Engineering Economist 64, 346-367. https://doi.org/10.1080/0013791X.2019.1580808

Wiegmans, B., Witte, P., Roso, V., 2019. Directional inland port development: Powerful strategies for inland ports beyond the inside-out/outside-in dichotomy. Research in Transportation Business \& Management 100415. https://doi.org/10.1016/j. rtbm.2019.100415

Wiegmans, B., Witte, P., Spit, T., 2015a. Characteristics of European inland ports: A statistical analysis of inland waterway port development in Dutch municipalities. Transportation Research Part A: Policy and Practice 78, 566-577. https://doi. org/10.1016/j.tra.2015.07.004

Wiegmans, B., Witte, P., Spit, T., 2015b. Inland Port Performance: A Statistical Analysis of Dutch Inland Ports. Transportation Research Procedia, Current practices in transport: appraisal methods, policies and models - 42nd European Transport Conference Selected Proceedings 8, 145-154. https://doi.org/10.1016/j. trpro.2015.06.050

Wiercx, M., van Kalmthout, M., Wiegmans, B., 2019. Inland waterway terminal yard configuration contributing to sustainability: Modeling yard operations. Research in Transportation Economics, Modal shift, emission reductions and behavioral change: Transport policies and innovations to tackle climate change 73, 4-16. https://doi. org/10.1016/j.retrec.2019.02.001

Wilmsmeier, G., Monios, J., Rodrigue, J.-P., 2015. Drivers for Outside-In port hinterland integration in Latin America: The case of Veracruz, Mexico. Research in Transportation Business \& Management, Operational constraints on effective governance of intermodal transport 14, 34-43. https://doi.org/10.1016/j. rtbm.2014.10.013

Witte, P., Wiegmans, B., Braun, C., Spit, T., 2016. Weakest link or strongest node? Comparing governance strategies for inland ports in transnational European corridors. Research in Transportation Business \& Management, Port Competitiveness: Issues and Challenges 19, 97-105. https://doi.org/10.1016/j.rtbm.2016.03.003

Witte, P., Wiegmans, B., Ng, A.K.Y., 2019. A critical review on the evolution and development of inland port research. Journal of Transport Geography 74, 53-61. https://doi.org/10.1016/j.jtrangeo.2018.11.001

Witte, P., Wiegmans, B., Rodrigue, J.-P., 2017. Competition or complementarity in Dutch inland port development: A case of overproximity? Journal of Transport Geography 60, 80-88. https://doi.org/10.1016/j.jtrangeo.2017.02.008

Witte, P., Wiegmans, B., van Oort, F., Spit, T., 2014. Governing inland ports: a multi-dimensional approach to addressing inland port-city challenges in European transport corridors. Journal of Transport Geography 36, 42-52. https://doi. org/10.1016/j.jtrangeo.2014.02.011

Wood, G., 2004. Tanzanian coastal and inland ports and shipping: crises and policy options. Maritime Policy \& Management 31, 157-171. https://doi. org/10.1080/0308883042000205052

Woxenius, J., Roso, V., Lumsden, K., 2004. The dry port concept-connecting seaports with their hinterland by rail.

Wu, X., Xiao, F., Liu, C.L., 2014. Key Points of Strategic Environmental Assessment on Inland Ports - A Case Study Based on Shaoguan Port Master Planning SEA [WWW Document]. Advanced Materials Research. https://doi.org/10.4028/www.scientific. net/AMR.955-959.1289

Yosef, T., Belachew, A., Tefera, Y., 2019. Magnitude and Contributing Factors of Low Back Pain among Long Distance Truck Drivers at Modjo Dry Port, Ethiopia: A CrossSectional Study [WWW Document]. Journal of Environmental and Public Health. https://doi.org/10.1155/2019/6793090

Zeng, Q., Maloni, M.J., Paul, J.A., Yang, Z., 2013. Dry port development in China: motivations, challenges, and opportunities. Transportation Journal 52, 234-263. https://doi.org/10.5325/transportationj.52.2.0234

Zhang, J., loannou, P.A., Chassiakos, A., 2006. Automated container transport system between inland port and terminals. ACM Trans. Model. Comput. Simul. 16, 95-118. https://doi.org/10.1145/1138464.1138465 